\title{
Transport into Mitochondria and Intramitochondrial Sorting of the Fe/S Protein of Ubiquinol-Cytochrome c Reductase
}

\author{
Franz-Ulrich Hartl," Bernd Schmidt," Elmar Wachter," \\ Hanns Weiss, ${ }^{\dagger}$ and Walter Neupert* \\ * Institut für Physiologische Chemie \\ der Universität München \\ Goethestrasse 33 \\ 8000 Munich 2, Federal Republic of Germany \\ †Institut für Biochemie \\ der Universität Düsseldorf \\ 4000 Düsseldorf, Federal Republic of Germany
}

\section{Summary}

The Fe/S protein of complex III is encoded by a nuclear gene, synthesized in the cytoplasm as a precursor with a 32 residue amino-terminal extension, and transported to the outer surface of the inner mitochondrial membrane. Our data suggest the following transport pathway. First, the precursor is translocated via translocation contact sites into the matrix. There, cleavage to an intermediate containing an eight residue extension occurs. The intermediate is then redirected across the inner membrane, processed to the mature subunit, and assembled into complex III. We suggest that the folding and membrane-translocation pathway in the endosymbiotic ancestor of mitochondria has been conserved during evolution of eukaryotic cells; transfer of the gene for Fe/S protein to the nucleus has led to addition of the presequence, which routes the precursor back to its "ancestral" assembly pathway.

\section{Introduction}

A number of general features of the transport of proteins into mitochondria have been elucidated (for reviews see Hay et al., 1984; Harmey and Neupert, 1985). First, completed polypeptide chains are released as precursors, most of which carry amino-terminal peptide extensions, from cytoplasmic ribosomes into precursor pools in the cytosol (Hallermayer et al., 1977; Schatz, 1979). Second, precursors are targeted to mitochondria by specific signals contained in the presequences (Hurt et al., 1984a, 1984b; Horwich et al.. 1985; Horwich et al., 1986; van Loon and Young, 1986) and by binding of precursors to proteinaceous receptors on the mitochondrial surface (Zwizinski et al., 1984). Third, insertion into and translocation across the outer and inner membrane are dependent on an electrical membrane potential (Schleyer et al., 1982; Gasser et al., 1982a; Kolanski et al., 1982; Pfanner and Neupert, 1985). Transport of precursors across the two mitochondrial membranes appears to occur in a single step via contact sites between outer and inner membranes (Schleyer and Neupert, 1985). Fourth, the proteins are proteolytically processed by a matrix-localized, metaldependent processing peptidase (Böhni et al., 1980; Miura et al., 1982; Conboy et al., 1982; McAda and Douglas, 1982; Schmidt et al., 1984). Finally, the proteins are assembled into various topological arrangements and complexes (Lewin and Norman, 1983; Schmidt et al., 1983; Dowhan et al., 1985).

These general reactions do not account for the sorting of precursors to the different submitochondrial locations. For this process, additional steps have been identified that apply to many precursor proteins. For instance, two-step proteolytic processing has been found for some proteins that either end up in the intermembrane space (Daum et al., 1982; Gasser et al., 1982b; Kaput et al., 1982) or at the outer face of the inner membrane and have a hydrophilic portion protruding into the intermembrane space (Gasser et al., 1982b; Ohashi et al., 1982; Teintze et al., 1982; Sadler et al., 1984). Modifications other than proteolysis are involved in the assembly of a number of proteins, and these include covalent or noncovalent addition of heme groups (Hennig and Neupert, 1981; Ohashi et al., 1982; Taniuchi et al., 1983), formation of iron-sulfur (Fe/S) clusters, and binding of metal ions or coenzymes. All these reactions, which vary among different proteins, could play a role in the specific sorting of a precursor protein.

In this report we describe studies of the transport pathway of the $\mathrm{Fe} / \mathrm{S}$ (Rieske) protein of the ubiquinolcytochrome $c$ reductase of the mitochondrial respiratory chain (complex III or bc $_{1}$ complex) (for reviews see Rieske, 1976; Trumpower, 1981; Beinert and Albracht, 1982). In particular, we ask how this protein is directed to its functional location, which is at the outer surface of the inner membrane (Bell et al., 1979; von Jagow and Sebald, 1980; Li et al., 1981b; Karlsson et al., 1983). There the large hydrophilic domain of the Fe/S protein (Harnisch et al., 1985) faces the intermembrane space. Our experiments suggest that the precursor to the $\mathrm{Fe} / \mathrm{S}$ protein is first completely transported into the matrix through translocation contact sites. This step is dependent on an electrical potential across the inner membrane. In the matrix the precursor is proteolytically processed and then redirected back across the inner membrane without further need for a membrane potential. In light of the endosymbiotic hypothesis for the origin of mitochondria, we argue that complete translocation across contact sites into the matrix leads the precursor back to its "ancestral" assembly pathway. In prokaryotes (e.g., Rhodopseudomonas sphaeroides) the homologous protein is apparently translocated across and folded into the membrane in a manner quite similar to the sorting of the processed, matrix-imported intermediate Fe/S protein in mitochondria (Gabellini et al., 1985; Gabellini and Sebald, 1986). We hypothesize that during evolution the primary amino acid sequence and the folding patterns and topological arrangements have been conserved, as well as the translocation and assembly pathways of precursor forms. 


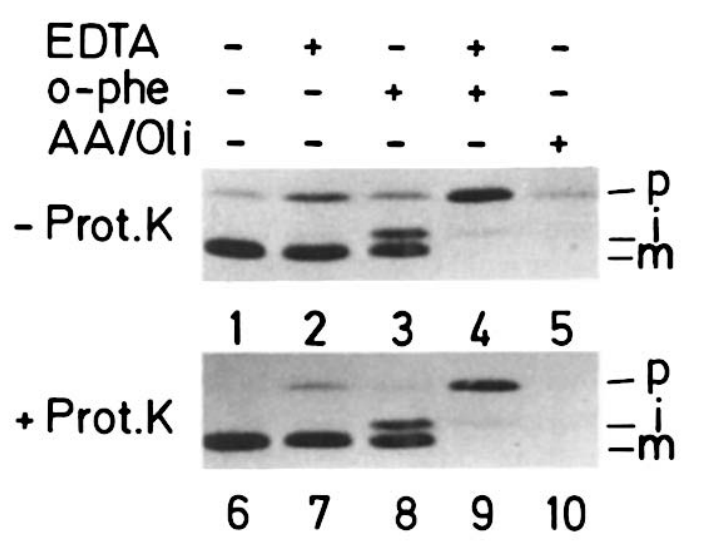

Figure 1. Import of $\mathrm{Fe} / \mathrm{S}$ Protein into Isolated Mitochondria $\mathrm{p}-\mathrm{Fe} / \mathrm{S}$ was synthesized in a reticulocyte lysate as described in Experimental Procedures. A postribosomal supernatant was prepared, supplemented with unlabeled methionine and sucrose, and diluted 1:2.5 with BSA buffer containing $2.5 \mathrm{mM} \mathrm{MgCl}$ (see Experimental Procedures). It was divided into five $500 \mu \mathrm{l}$ aliquots, and each was brought to $2 \mathrm{mM} \mathrm{NADH}$ and $2 \mathrm{mM}$ reduced glutathione. Where indicated, EDTA, o-phenanthroline (o-phe), or antimycin and oligomycin (AA/Oli) was added. Each reaction received mitochondria to a final concentration of $0.1 \mathrm{mg} / \mathrm{ml}$, and was incubated for $30 \mathrm{~min}$ at $25^{\circ} \mathrm{C}$. After reactions were cooled to $0^{\circ} \mathrm{C}$, mitochondria were reisolated, resuspended in $200 \mu \mathrm{l}$ of SEM buffer containing 0-phenanthroline, and divided into two portions. One portion was left on ice for $30 \mathrm{~min}$ (- Prot. $K$ ) (lanes 1-5), and the other was treated with proteinase $\mathrm{K}$ (+ Prot. K) as described in Experimental Procedures (lanes 6-10). After addition of PMSF to all reactions, mitochondria were sedimented and dissociated, Fe/S protein was immunoprecipitated, and precipitates were analyzed, as described in Experimental Procedures. A fluorograph of the dried gel is shown. The positions of $p-F e / s(p), i-F e / S(i)$, and $m-F e / S$ (m) are indicated.

\section{Results}

\section{Transport and Processing of the Precursor to Fe/S Protein into Mitochondria Occurs via an Intermediate-Sized Form}

Precursor to the Fe/S protein ( $p-F e / S$ ) was synthesized in a reticulocyte lysate that was programmed with $\mathrm{Neu}$ rospora poly $(A)^{+}$RNA in the presence of [ ${ }^{35}$ S]methionine, and it was incubated with isolated mitochondria. The precursor was imported into mitochondria and was processed to the size of the mature $\mathrm{Fe} / \mathrm{S}$ protein $(\mathrm{m}-\mathrm{Fe} / \mathrm{S}$ ) present in the assembled complex III (Figure 1, lane 1). Import into the interior of the mitochondrion was demonstrated by the resistance of the $\mathrm{m}-\mathrm{Fe} / \mathrm{S}$ in mitochondria to proteinase $K$ treatment (Figure 1, lane 6). The small amount of $\mathrm{p}-\mathrm{Fe} / \mathrm{S}$ associated with mitochondria was protease-sensitive, suggesting a localization on the surface. Addition of the nonpenetrating chelator EDTA to the import reaction caused a slight increase in the amount of $\mathrm{p}-\mathrm{Fe} / \mathrm{S}$ associated with mitochondria, some of which was protease-resistant (Figure 1, lanes 2 and 7). The membrane-permeable metal chelator o-phenanthroline caused a substantial reduction of processing to the mature form. Notably, an intermediate-sized form of the Fe/S protein (i-Fe/S) was detected inside the mitochondrion, since it was as resistant to protease as $\mathrm{m}$-Fe/S (Figure 1, lanes 3 and 8 ). When EDTA and o-phenanthroline treatments were combined, a considerable amount of $\mathrm{p}-\mathrm{Fe} / \mathrm{S}$ was found as

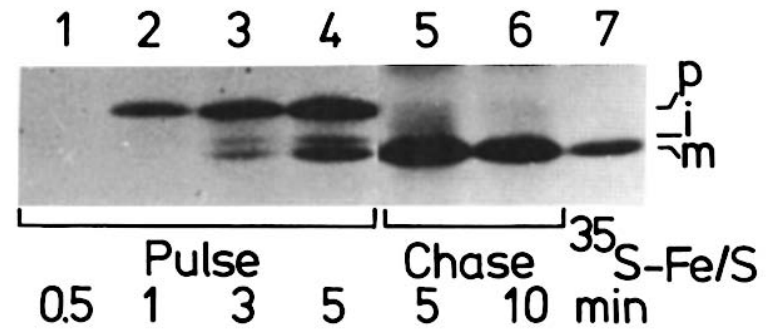

Figure 2. Import of Fe/S Protein In Vivo

A culture of Neurospora was grown for $14 \mathrm{hr}$ to a content of $3 \mathrm{~g}$ cells (wet weight) per liter. The culture was cooled to $8^{\circ} \mathrm{C}$, and $0.5 \mathrm{mCi}$ of [ ${ }^{3} \mathrm{H}$ ]leucine was added to $45 \mathrm{mg}$ of cells (in a volume of $15 \mathrm{ml}$ ). After $0.5,1,3$, and $5 \mathrm{~min}$, aliquots containing $5 \mathrm{mg}$ of cells were rapidly precipitated with ice-cold trichloroacetic acid (final concentration 0.4 M) (lanes 1-4). To the remaining part of the culture, a chase solution of $1 \mathrm{mM}$ unlabeled leucine and $50 \mu \mathrm{g} / \mathrm{ml}$ of cycloheximide (final concentrations) was added, and after one more minute at $8^{\circ} \mathrm{C}$ the temperature was raised to $25^{\circ} \mathrm{C}$. Al 5 and $10 \mathrm{~min}$ after addition of the chase solution, samples were withdrawn and were immediately precipitated with trichloroacetic acid (lanes 5 and 6). As a control, Fe/S protein was immunoprecipitated from cells labeled overnight with $\left[^{35}\right.$ S] sulfate and was applied in lane 7. Fe/S protein species are indicated as in Figure 1.

the only species associated with mitochondria. Most important, this form of $\mathrm{p}$-Fe/S was not accessible to protease (i.e., was at least beyond the outer membrane; Figure 1, lanes 4 and 9). This observation confirms the earlier finding that precursors can be imported into mitochondria in the absence of proteolytic processing (Zwizinski and Neupert, 1983). Import of the precursor depends on the mitochondrial membrane potential. In the presence of antimy$\operatorname{cin} A$ and oligomycin a very small amount of $p-F e / S$ was found with mitochondria, and it was completely removed by protease treatment (Figure 1, lanes 5 and 10).

Import of p-Fe/S showed a strong requirement for an oxidizable substrate such as NADH, succinate, or ascorbate plus $N, N, N^{\prime}, N^{\prime}$-tetramethylphenylenediamine (not shown). In the absence of these substrates, import in undiluted reticulocyte lysate was largely diminished, and in lysate diluted with buffer it was completely abolished. Under the same conditions, import of the ADPIATP carrier (Pfanner and Neupert, 1985) or of subunit 9 of ATPase did not show such a requirement. It remains to be determined whether the $\mathrm{Fe} / \mathrm{S}$ protein requires a higher membrane potential than other precursors for import or whether electron flow is necessary for some other reaction, as found for the assembly of cytochrome $c_{1}$, for example (Schleyer and Neupert, 1985).

The question arises as to whether $\mathrm{i}-\mathrm{Fe} / \mathrm{S}$ is indeed a physiological intermediate in the import pathway. Intact cells were pulse-labeled with $\left[{ }^{3} \mathrm{H}\right]$ leucine at low temperature $\left(8^{\circ} \mathrm{C}\right)$ for up to $5 \mathrm{~min}$. At various time points cells were withdrawn from the culture, immediately treated with trichloroacetic acid, and boiled in buffer containing sodium dodecyl sulfate (SDS); after addition of Triton X-100 the $\mathrm{Fe} / \mathrm{S}$ protein was immunoprecipitated. Figure 2 shows that first $\mathrm{p}-\mathrm{Fe} / \mathrm{S}$ appeared, and with time both $\mathrm{i}-\mathrm{Fe} / \mathrm{S}$ and $\mathrm{m}-\mathrm{Fe} / \mathrm{S}$ were formed. After a chase at $25^{\circ} \mathrm{C}$ with unlabeled leucine, $\mathrm{p}-\mathrm{Fe} / \mathrm{S}$ and $\mathrm{i}-\mathrm{Fe} / \mathrm{S}$ disappeared and $\mathrm{m}-\mathrm{Fe} / \mathrm{S}$ accumulated. Obviously, i-Fe/S is not an in vitro artifact but is 


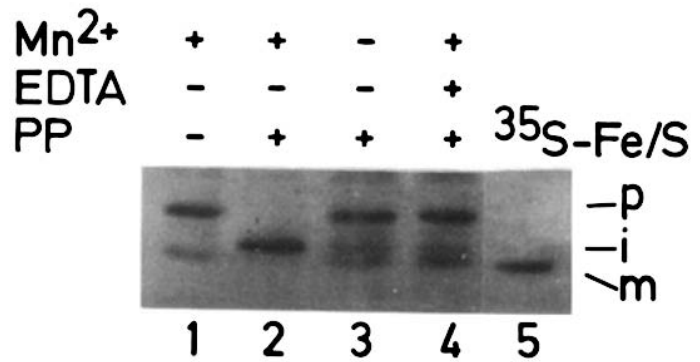

Figure 3. Processing of p-Fe/S by Purified Processing Peptidase

A reticulocyte lysate containing labeled $p-F e / S$ was desalted on a Sephadex G-25 column equilibrated with $30 \mathrm{mM}$ Tris- $\mathrm{HCl}(\mathrm{pH} \mathrm{8.2)}$ Four aliquots of $50 \mu \mathrm{l}$ each were made $1 \%$ in Triton $X-100$ and $1 \mathrm{mM}$ in PMSF (lanes 1-4). Reactions 1, 2, and 4 received $2 \mathrm{mM} \mathrm{MnCl}$. To reaction 4, 3 mM EDTA was added. Reactions 2-4 each received 10 $\mu \mathrm{l}$ of a diluted fraction containing processing peptidase (PP) from $\mathrm{Neu}$ rospora mitochondria enriched about 2000-fold. After incubation for 1 $\mathrm{hr}$ at $25^{\circ} \mathrm{C}$, the reactions were stopped by the addition of $\mathrm{NaCl}$ and EDTA to final concentrations of $0.5 \mathrm{M}$ and $8 \mathrm{mM}$, respectively. The reactions were diluted with Triton buffer and were immunoprecipitated. In addition, $\mathrm{m}-\mathrm{Fe} / \mathrm{S}$ was immunoprecipitated from mitochondria labeled in vivo with [ ${ }^{35}$ S]sulfate (lane 5 ). The precipitates were electrophoresed and then fluorographed. Fe/S protein species are indicated as in Figure 1.

indeed an intermediate in the assembly pathway in vivo. Similarly, in labeling experiments in vivo with yeast cells, an intermediate-sized form of the $\mathrm{Fe} / \mathrm{S}$ subunit has been described; its significance, however, was not further investigated (Sidhu and Beattie, 1983).

What is the structure of $\mathrm{i}-\mathrm{Fe} / \mathrm{S}$ ? A partially purified preparation of the processing peptidase was able to cleave p-Fe/S selectively to i-Fe/S (Figure 3, lanes 1 and 2). The reaction required $\mathrm{Mn}^{2+}$ ions (or other divalent metal ions like $\mathrm{Zn}^{2+}$ or $\mathrm{Co}^{2+}$ ), as has been noted previously with other precursor proteins and other organisms (Figure 3, lane 3) (Böhni et al., 1980; Conboy et al., 1982; Schmidt et al., 1984). If the $\mathrm{Mn}^{2+}$ was complexed by EDTA, processing was blocked (Figure 3, lane 4).

Is the difference in apparent molecular weight between $\mathrm{i}-\mathrm{Fe} / \mathrm{S}$ and $\mathrm{m}-\mathrm{Fe} / \mathrm{S}$ due to an additional sequence of amino acids or to some modification that alters the electrophoretic mobility on SDS-polyacrylamide gels? To analyze the amino terminus of $\mathrm{i}-\mathrm{Fe} / \mathrm{S}, \mathrm{p}-\mathrm{F} / \mathrm{S}$ was synthesized in a reticulocyte lysate in the presence of $\left[{ }^{3} \mathrm{H}\right]$ phenylalanine or [ $\left.{ }^{3} \mathrm{H}\right]$ leucine. It was processed with the partially purified matrix protease, immunoprecipitated, and fractionated by SDS-polyacrylamide gel electrophoresis. The i-Fe/S band was then excised and was subjected to automated Edman degradation on a solid-phase sequencer (Wachter et al., 1973; Figure 4A). For comparison, m-Fe/S obtained by immunoprecipitation from cells labelled in vivo with $\left[{ }^{3} \mathrm{H}\right]$ phenylalanine was also analyzed by Edman degradation (Figure 4B). In the latter case, as expected from cDNA sequence analysis (Harnisch et al., 1985), radioactive phenylalanine was released in steps 7 and 11. In contrast, $\left[{ }^{3} \mathrm{H}\right]$ phenylalanine from labeled $\mathrm{i}-\mathrm{Fe} / \mathrm{S}$ did not appear until steps 15 and 19 (Figure 4A). When i-Fe/S that had been labeled with $\left[{ }^{3} \mathrm{H}\right]$ leucine was sequenced, radioactivity was released in step 7 (Figure 4A). Comparison with the amino acid sequence derived from the cDNA sequence
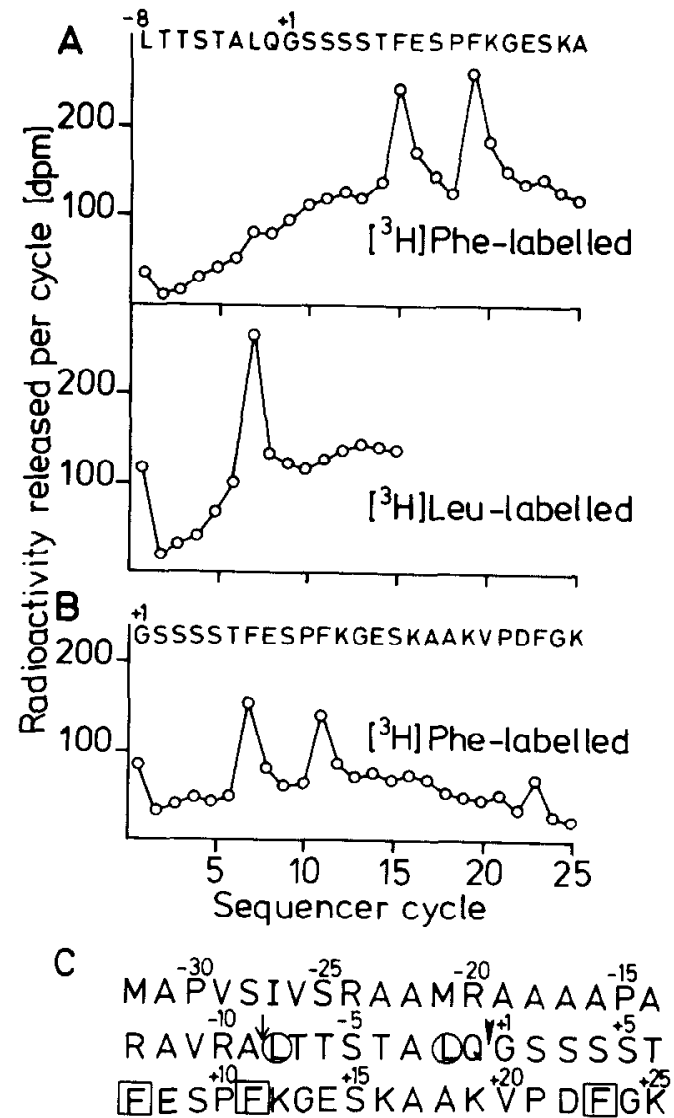

Figure 4. Sequence Analysis of $\mathrm{i}-\mathrm{Fe} / \mathrm{S}$ and Mature-Sized $\mathrm{Fe} / \mathrm{S}$ Protein (A) p-Fe/S was synthesized in reticulocyte lysates in the presence of $\left[{ }^{3} \mathrm{H}\right]$ phenylalanine (upper panel) or $\left[{ }^{3} \mathrm{H}\right.$ leucine (lower panel). i-Fe/S was generated as described in the legend to Figure 3 and was immunoprecipitated. The precipitate was subjected to electrophoresis. i$\mathrm{Fe} / \mathrm{S}$ was eluted from the gels $(30,000 \mathrm{dpm}$ and $35,000 \mathrm{dpm}$, respectively) and was subjected to 25 steps of solid-phase Edman degradation. The sequence of the corresponding amino acids is shown; +1 marks the amino terminus of $\mathrm{m}-\mathrm{Fe} / \mathrm{S}$. Leucine in position -8 could not be detected by this procedure since amino-terminal amino acids are coupled to the solid support via the free $\alpha$-amino group. This bond is not cleaved during the normal Edman cycle.

(B) A $400 \mathrm{ml}$ culture of Neurospora hyphae grown for $14 \mathrm{hr}(1.5 \mathrm{~g}$ wet weight of cells) was incubated for $45 \mathrm{~min}$ at $25^{\circ} \mathrm{C}$ in the presence of $3 \mathrm{mCi}\left[{ }^{3} \mathrm{H}\right]$ phenylalanine. Mitochondria were isolated, and $\mathrm{Fe} / \mathrm{S}$ protein was immunoprecipitated and electrophoresed. $\mathrm{m}$-Fe/S was eluted from the gel $(20,000 \mathrm{dpm})$ and was sequenced.

(C) Amino acid sequence of $\mathrm{p}-\mathrm{Fe} / \mathrm{S}$ deduced from the cDNA sequence (Harnisch et al., 1985). Arrow indicates the cleavage site of the matrix peptidase; the amino terminus of $\mathrm{i}-\mathrm{Fe} / \mathrm{S}$ is at -8 in the sequence. $\mathrm{Ar}$ rowhead indicates the cleavage site of the second processing enzyme; the amino terminus of $\mathrm{m}-\mathrm{Fe} / \mathrm{S}$ is at $+\mathbf{1}$. Labeled amino acids leucine (circles) and phenylalanine (squares) are indicated.

(Harnisch et al., 1985) shows that the cleavage site of the processing peptidase is eight amino acids before the beginning of the mature protein, and that $\mathrm{i}-\mathrm{Fe} / \mathrm{S}$ is indeed a proteolytically processed intermediate (Figure $4 \mathrm{C}$ ). The second processing step was apparently sensitive to o-phenanthroline (see Figure 1), although the inhibition was not complete even at higher concentrations of chelator (not shown). It is unclear whether processing is inhibited because the cleaving enzyme has a metal requirement, or whether the second processing step is only 
A

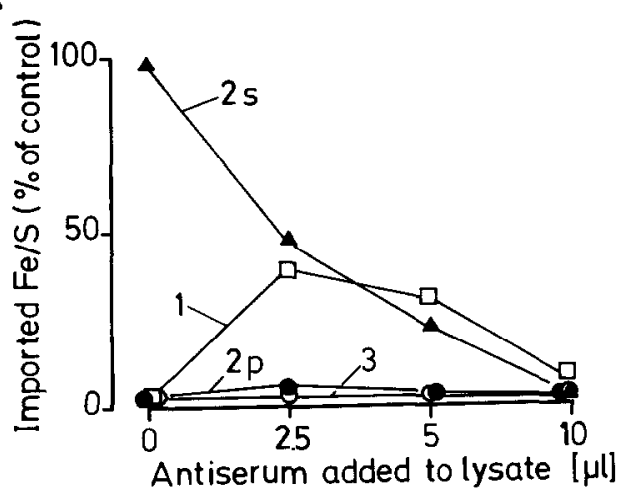

B

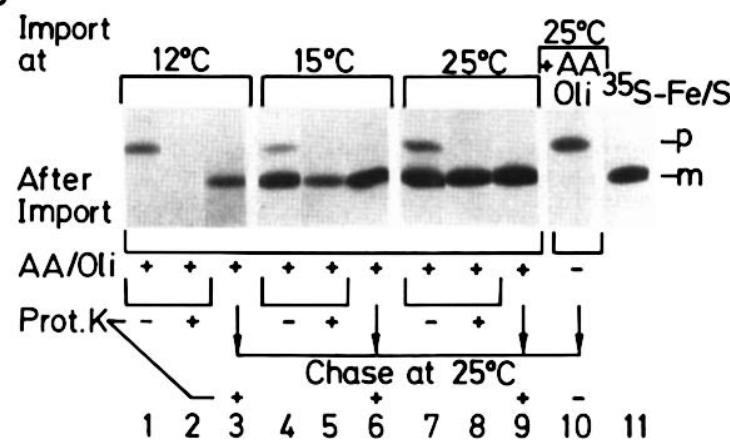

Figure 5. Import of Fe/S Protein via Translocation Contact Sites

(A) Four hundred microliter portions of supplemented reticulocyte lysate (see Figure 1) received $0,2.5,5$, or $10 \mu$ lof anti-Fe/S antiserum. Samples were incubated for $15 \mathrm{~min}$ at $0^{\circ} \mathrm{C}$, and then divided into three (reactions 1-3). Reactions 3 received antimycin A and oligomycin. Mitochondria were added to all samples, and incubation was for $30 \mathrm{~min}$ at $25^{\circ} \mathrm{C}$. After cooling to $0^{\circ} \mathrm{C}$, reactions 2 were treated with proteinase $K$, while other reactions remained on ice. PMSF was added to all samples, and mitochondria were reisolated. Reactions 1 received a 20-fold excess of unlabeled mitochondria solubilized in Triton buffer; other samples received the same volume of buffer alone. After a clarifying spin, all samples received protein A-Sepharose. After the samples were shaken for $1 \mathrm{hr}$ at $4^{\circ} \mathrm{C}$. immunoprecipitates were sedimented, washed, and dissociated (reactions 1, 2p, 3). To the supernatants of reactions 2, anti-Fe/S antibody was added to precipitate imported $\mathrm{Fe} / \mathrm{S}$ protein not prebound to antibody (reaction 2s). Processed Fe/S protein was analyzed by electrophoresis followed by fluorography and densitometry. Data are expressed as a percentage of $\mathrm{m}-\mathrm{Fe} / \mathrm{S}$ imported in the absence of added antibody. Open squares, reactions 1; closed circles, reactions $2 p$; open circles, reactions 3 ; closed triangles, reactions 2s.

(B) Mitochondria were analyzed for import by incubation in reticulocyte lysate for $30 \mathrm{~min}$ at $12^{\circ} \mathrm{C}, 15^{\circ} \mathrm{C}$, or $25^{\circ} \mathrm{C}$. The samples were cooled to $0^{\circ} \mathrm{C}$, antimycin $\mathrm{A}$ and oligomycin were added, and the samples were divided into three. For one group, mitochondria were immediately reisolated, and $\mathrm{Fe} / \mathrm{S}$ protein was immunoprecipitated (lanes 1, 4, 7). The second group was treated with proteinase $K$ as described in Experimental Procedures, and mitochondria were reisolated for immunoprecipitation (lanes $2,5,8$ ). The third group was further incubated for $20 \mathrm{~min}$ at $25^{\circ} \mathrm{C}$, then cooled and treated with proteinase $\mathrm{K}$ (lanes 3,6 , 9). As a control for inhibition of membrane potential, a separate reaction received antimycin $A$ and oligomycin before incubation of mitochondria in the lysate (for $55 \mathrm{~min}$ at $25^{\circ} \mathrm{C}$ ) (lane 10). Immunoprecipitates were dissoclated and electrophoresed. A fluorograph of the dried gel is shown. Lane 11 shows $\mathrm{m}$-Fe/S from mitochondria labeled in vivo with $\left[{ }^{35} \mathrm{~S}\right]$ sulfate. Abbreviations are as in Figure 1. possible after formation of the $\mathrm{Fe} / \mathrm{S}$ center, a reaction that may also be inhibited by metal chelators.

\section{Import of Fe/S Protein Occurs through Translocation Contact Sites}

We have previously reported that after binding of antibodies to the precursors of ATPase subunit 2 or cytochrome $c_{1}$, partial import of the polypeptide chains into isolated mitochondria takes place. In both cases the amino terminus of the translocational intermediate is in the matrix (where it can be cleaved by the processing peptidase) while the major portion is still outside the outer membrane (where it is attached to the antibody and can be digested by externally added proteases) (Schleyer and Neupert, 1985). This finding suggested that these precursors are transported into mitochondria via translocation contact sites, in which the two membranes come close enough together to be spanned by part of the precursor polypeptide. Similar experiments were performed with the Fe/S protein. Antibodies against $\mathrm{Fe} / \mathrm{S}$ protein were added in increasing amounts to the reticulocyte lysate containing the labeled precursor. Import was performed, and the antibody-Fe/S protein complexes were harvested by adding protein A-Sepharose. Formation of $\mathrm{m}-\mathrm{Fe} / \mathrm{S}$ could indeed be seen under these conditions (Figure $5 A$, reaction 1), and the partial import of the p-Fe/S-antibody complex was inhibited by dissipating the membrane potential (reaction 3). When very high amounts of antibody were added, the amount of the translocational intermediate formed was reduced, apparently because the precursor was masked by the antibody in the lysate. The antibodybound, processed species was entirely sensitive to proteinase $\mathrm{K}$ added to intact mitochondria, since after this treatment no more $\mathrm{Fe} / \mathrm{S}$ protein could be harvested with protein A-Sepharose (Figure $5 \mathrm{~A}$, reaction $2 p$ ). This confirmed that a major portion of the $\mathrm{Fe} / \mathrm{S}$ protein-antibody complex was still on the surface of the mitochondria. When antibodies against $\mathrm{Fe} / \mathrm{S}$ protein were added to these protease-treated mitochondria after dissolving them in buffer containing Triton $X-100$, some $m-F e / S$ was precipitated (Figure $5 A$, reaction $2 s$ ). This $\mathrm{m}-\mathrm{Fe} / \mathrm{S}$ apparently bypassed the antibody block, as has been reported for other precursors (Schleyer and Neupert, 1985). The smaller the initial amount of antibody added to the lysate, the more $\mathrm{Fe} / \mathrm{S}$ protein bypassed the antibody block.

To confirm the conclusions from this experiment, another approach was used to show import of Fe/S protein via translocation contact sites. Import of p-Fe/S into isolated mitochondria was carried out at various temperatures between $2^{\circ} \mathrm{C}$ and $25^{\circ} \mathrm{C}$. At $2^{\circ} \mathrm{C}$ to $8^{\circ} \mathrm{C}$ practically no formation of $\mathrm{m}-\mathrm{Fe} / \mathrm{S}$ occurred (not shown), whereas at $25^{\circ} \mathrm{C}$ almost all $\mathrm{Fe} / \mathrm{S}$ protein was present as proteaseprotected $\mathrm{m}-\mathrm{Fe} / \mathrm{S}$ (Figure 5B). At $12^{\circ} \mathrm{C}$, p-Fe/S but very litthe $\mathrm{i}-\mathrm{Fe} / \mathrm{S}$ and $\mathrm{m}-\mathrm{Fe} / \mathrm{S}$ were found associated with mitochondria. At $15^{\circ} \mathrm{C}$, however, a considerable amount of $\mathrm{m}-\mathrm{Fe} / \mathrm{S}$ could be detected. All these species were largely sensitive to added proteinase $K$. When mitochondria were treated with antimycin $A$ and oligomycin after partially importing $\mathrm{Fe} / \mathrm{S}$ protein at intermediate temperatures and then being warmed up to $25^{\circ} \mathrm{C}$, protease-protected m-Fe/S 


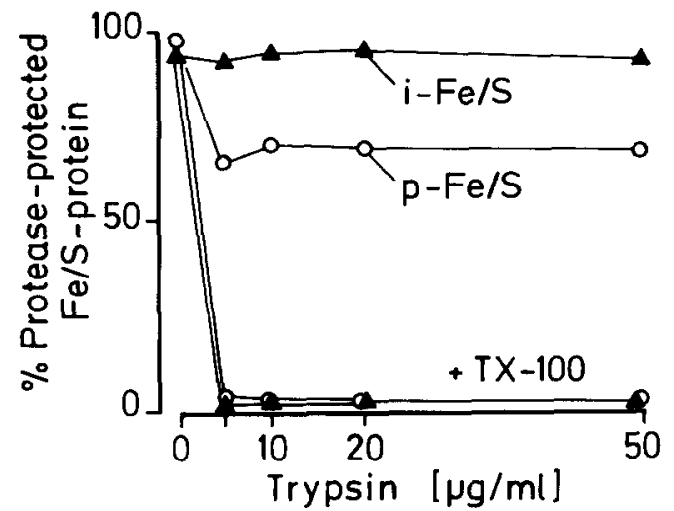

Figure 6. Resistance of Imported $\mathrm{p}-\mathrm{Fe} / \mathrm{S}$ and $\mathrm{i}-\mathrm{Fe} / \mathrm{S}$ to Added Protease $\mathrm{p}$-Fe/S was imported into isolated mitochondria (see Figure 1). The reactions contained EDTA and o-phenanthroline to inhibit the matrix peptidase. Mitochondria were reisolated and were resuspended at a concentration of $0.25 \mathrm{mg} / \mathrm{ml}$ in SEM buffer (see Experimental Procedures) containing $0.5 \mathrm{mM}$ o-phenantroline. Aliquots containing $25 \mu \mathrm{g}$ mitochondria were treated with trypsin at concentrations of up to 50 $\mu \mathrm{g} / \mathrm{ml}$ and were incubated for $30 \mathrm{~min}$ at $0^{\circ} \mathrm{C}$. Control reactions received $1 \%$ Triton X-100 prior to the addition of trypsin. Protease action was stopped by addition of a 30 -fold excess $(w / w)$ of soy bean trypsin inhibitor. The reactions were diluted 10 -fold with Triton buffer, and $\mathrm{Fe} / \mathrm{S}$ protein was immunoprecipitated. After electrophoresis dried gels were fluorographed, and bands were quantified by densitometry. Films were exposed for various times to verify a linear dependence of absorption on the amount of radioactivity in the bands.

was formed (Figure 5B). These findings indicate that translocational intermediates of Fe/S protein can be accumulated for which the amino terminus is apparently located at the inner face of the inner membrane (since a membrane potential is no longer required for complete translocation into the matrix), but a major part of the polypeptide is still outside of the outer membrane. In summary, $\mathrm{Fe} / \mathrm{S}$ protein appears to be imported in a way similar to that previously shown for subunit 2 of ATPase and for cytochrome $c_{1}$; for both of these proteins, at a certain time in the import pathway the polypeptide chain spans both the outer and inner membranes (Schleyer and Neupert, 1985).

In the Absence of Proteolytic Processing, Precursor Is Imported into the Matrix Space As already demonstrated (Figure 1, lanes 4 and 9), p-Fe/S imported in the presence of EDTA and o-phenanthroline (i.e., when the processing peptidase in the matrix is inhibited [Schmidt et al., 1984]) was resistant to added protease. Titration of trypsin sensitivity showed resistance of $\mathrm{p}-\mathrm{Fe} / \mathrm{S}$ even at high concentrations of the protease. In the presence of Triton X-100, p-Fe/S was completely degraded by trypsin even at very low concentrations. The i-Fe/S formed in the presence of o-phenanthroline was resistant to trypsin at all concentrations applied in the absence, but not in the presence, of Triton X-100 (Figure 6). Apparently, imported $p$-Fe/S and $i-F e / S$ are inside the mitochondrion, or have at least crossed the outer membrane.

Is imported $\mathrm{m}$-Fe/S inserted in the mitochondrial inner membrane, or is it a soluble species? Extractability of the various species of $\mathrm{Fe} / \mathrm{S}$ protein with sodium carbonate

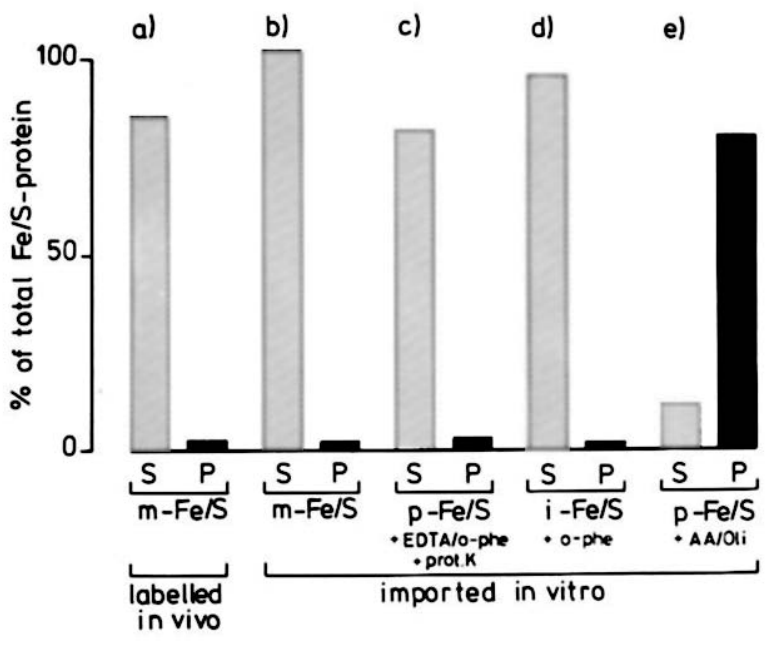

Figure 7. Extractability of the Different Forms of Fe/S-Protein with 0.1 M Sodium Carbonate

Mitochondria from Neurospora cells either labeled overnight with $\left[{ }^{35} \mathrm{~S}\right]$ sulfate $(a)$ or recovered after import in vitro $(b-e)$ were resuspended in $0.1 \mathrm{M} \mathrm{Na}_{2} \mathrm{CO}_{3}$ at a protein concentration of $0.1 \mathrm{mg} / \mathrm{ml}$ and were incubated for $30 \mathrm{~min}$ at $0^{\circ} \mathrm{C}$. The samples were divided into two parts. One part was designated "total" ( $T$ ) and was kept on ice as a reference for determination of recoveries. The second half was separated into supernatants $(S)$ and pellets $(P)$ by centrifugation for $1 \mathrm{hr}$ at $165,000 \times \mathrm{g}$. For immunoprecipitation, fractions $\mathrm{T}$ and $\mathrm{S}$ were made $1 \%$ in Triton X-100 and $5 \mathrm{mM}$ in EDTA, neutralized to $\mathrm{pH} 7.4$ with 0.2 $\mathrm{M} \mathrm{NaH}{ }_{2} \mathrm{PO}_{4}$, and diluted 2-fold with Triton buffer. Fractions $P$ were solubilized in SDS-containing buffer and were diluted to the same volume as fractions $T$ and $S$ with Triton buffer. Antiserum directed against $\mathrm{Fe} / \mathrm{S}$ protein was added, and the immune complexes were harvested with protein A-Sepharose. Fluorographs of dried gels were quantified by densitometry. (a) Assembled $\mathrm{m}$-Fe/S from mitochondria labeled in vivo; (b) $\mathrm{m}$-Fe/S imported in vitro; (c) $\mathrm{p}$ - $\mathrm{Fe} / \mathrm{S}$ imported into mitochondria in the presence of EDTA and o-phenanthroline; (d) i-Fe/S accumulated in mitochondria in the presence of o-phenanthroline; (e) $\mathrm{p}-\mathrm{Fe} / \mathrm{S}$ bound to mitochondria after the membrane potential was dissipated with antimycin $\mathrm{A}$ and oligomycin. Experimental conditions for import in vitro were essentially as described in Figure 1.

was analyzed (Fujiki et al., 1982) (Figure 7). Mature Fe/S protein, assembled into complex III and labeled in vivo, was found to be almost completely soluble when mitochondria were treated with $0.1 \mathrm{M}$ sodium carbonate. In agreement with this, $\mathrm{Fe} / \mathrm{S}$ protein imported into mitochondria in vitro and processed to $\mathrm{m}-\mathrm{Fe} / \mathrm{S}$ was soluble under the same conditions (Figure 7). This confirms the suggestion that the Rieske Fe/S protein is a peripheral subunit of complex III in the inner mitochondrial membrane (Rieske, 1976; Li et al., 1981b), where it faces toward the intermembrane space and interacts with cytochrome $c_{1}$, whose heme-containing portion is known to protrude into the intermembrane space (Li et al., 1981a; Trumpower, 1981; Edwards et al., 1982). The extractability with sodium carbonate of the $\mathrm{Fe} / \mathrm{S}$ protein is exceptional compared with the extractability of the other subunits of complex III; the two core proteins, cytochrome $b$ and cytochrome $c_{1}$, are resistant to sodium carbonate extraction (not shown).

Imported $\mathrm{p}-\mathrm{Fe} / \mathrm{S}$ and $\mathrm{i}-\mathrm{Fe} / \mathrm{S}$ were found to be soluble in sodium carbonate, suggesting that these forms are not integrated into the phospholipid bilayer of the membrane, either (Figure 7). In contrast, p-Fe/S associated with mito- 

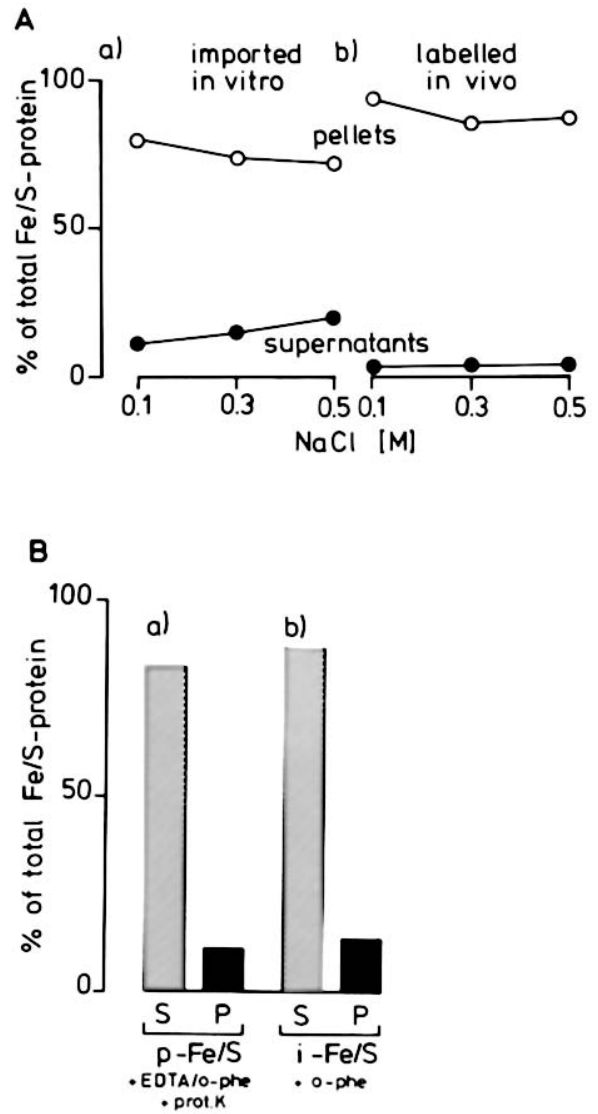

Figure 8 . Extractability of the Different Forms of Fe/S Protein with Salt (A) Imported $\mathrm{m}$ - $\mathrm{Fe} / \mathrm{S}$ and $\mathrm{m}$ - $\mathrm{Fe} / \mathrm{S}$ assembled in vivo are resistant to extraction in high salt. Mitochondria reisolated from a standard import reaction (a) and mitochondria labeled in vivo with $\left[{ }^{35} \mathrm{~S}\right]$ sulfate (b) were resuspended at $0.1 \mathrm{mg} / \mathrm{ml}$ in SEM buffer containing varying concentrations of $\mathrm{NaCl}(0.1-0.5 \mathrm{M})$. Samples were sonicated as in Experimental Procedures and were divided into two parts. The first part was kept on ice to serve as control for recovery determinations. The second was separated into supernatant and pellet by centrifugation. For immunoprecipitation of $\mathrm{Fe} / \mathrm{S}$ protein, controls and supernatants were brought to $300 \mathrm{mM} \mathrm{NaCl}, 1 \%$ Triton X-100, and $5 \mathrm{mM}$ EDTA. Pellets were solubilized in SDS-containing buffer and were diluted with Triton buffer. The dissociated immune complexes were subjected to electrophoresis. Fluorographs of dried gels were quantified by densitometry. Values are expressed as a percentage of total mitochondria-associated m-Fe/S. (B) p-Fe/S and i-Fe/S imported into mitochondria in vitro are extractable with low salt. Import reactions contained EDTA and o-phenanthroline (a) or o-phenanthroline alone (b) to accumulate p-Fe/S and i-Fe/S, respectively. In (a), precursor bound to the surface of mitochondria was digested with added proteinase $K$. The import reactions were then centrifuged, and the mitochondrial pellets were resuspended in SEM buffer containing $100 \mathrm{mM} \mathrm{NaCl}$ and were treated as in (A). Data are expressed as a percentage of total imported $\mathrm{Fe} / \mathrm{S}$ protein.

chondria after transier in the absence of a membrane potential was largely resistant to sodium carbonate extraction. This $p-F e / S$ could not be further imported when a membrane potential was reestablished. It may be a species that is unspecifically inserted into the membrane.

The solubility of imported $\mathrm{p}-\mathrm{Fe} / \mathrm{S}$ in buffers of different ionic strength was analyzed. For comparison, the solubility of the mature $\mathrm{Fe} / \mathrm{S}$ protein present in the assembled complex was determined. At all salt concentrations applied $(0.1-0.5 \mathrm{M} \mathrm{NaCl}$ in Mops buffer), assembled $\mathrm{Fe} / \mathrm{S}$
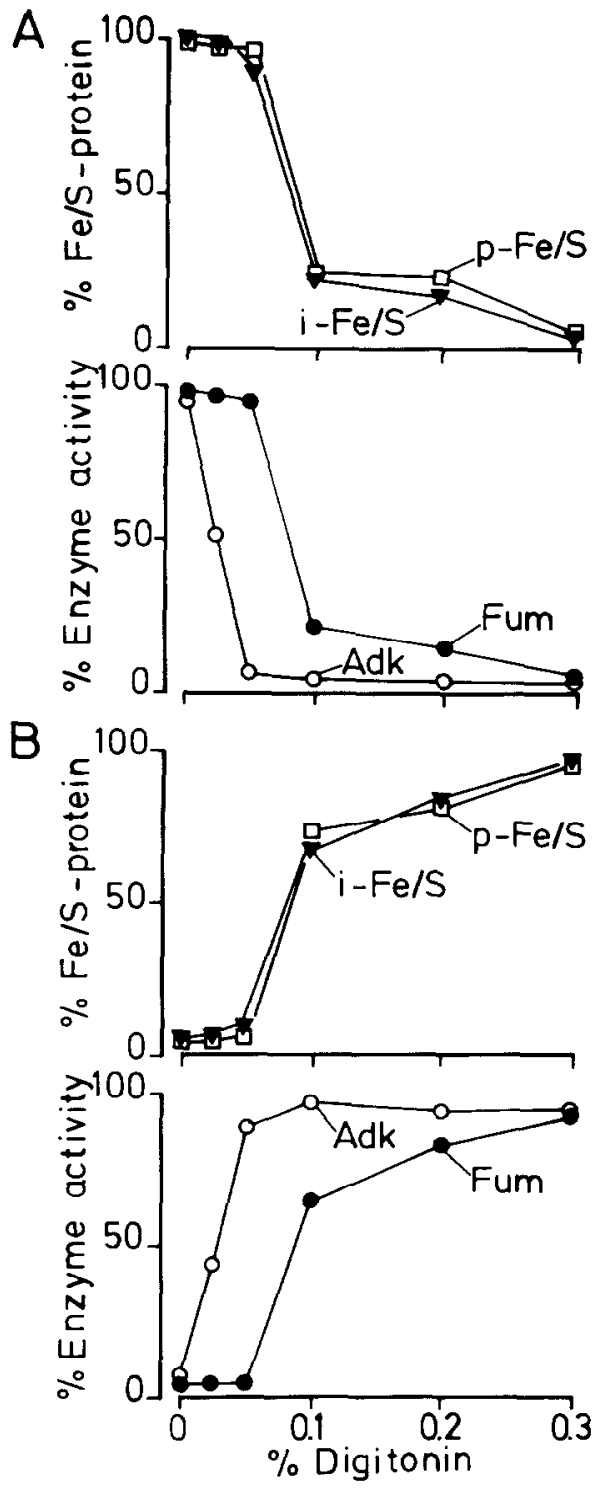

Figure 9. Release of Imported p-Fe/S and i-Fe/S from Mitochondria by Treatment with Digitonin

p-Fe/S contained in reticulocyte lysates (diluted 10-fold with BSA buffer) was imported in vitro in the presence of EDTA and o-phenanthroline (see Figure 1). Mitochondria were reisolated from the import reactions, resuspended in SEM buffer containing $0.1 \mathrm{mM}$ o-phenanthroline, and treated with proteinase $\mathrm{K}$. After the protease was inhibited with PMSF, mitochondria were reisolated and were resuspended at a concentration of $10 \mathrm{mg} / \mathrm{ml}$ in SEMK medium (see Experimental Procedures) containing $0.1 \mathrm{mM}$ o-phenanthroline, $0.1 \mathrm{mM}$ PMSF, and cytosolic protease inhibitor fraction from Neurospora crassa $(0.5 \mathrm{mg} / \mathrm{ml} \mathrm{fi-}$ nal concentration). Digitonin treatment was performed as outlined in Experimental Procedures, and the fractions were separated into pellets and supernatants by centrifugation. Pellets were resuspended in SEMK medium containing $1 \%(w / v)$ Genapol (Hoechst AG, Frankfurt) to the same volume as the supernatants, which were also supplemented with Genapol to a final concentration of $1 \%$. Aliquots of these fractions (corresponding to $20 \mu \mathrm{g}$ of mitochondria) were used for determination of marker enzymes and for immunoprecipitation of $\mathrm{Fe} / \mathrm{S}$ protein. The precipitates were electrophoresed, and fluorographs were quantified by densitometry. For determination of recoveries, total enzyme activities and amounts of immunoprecipitable $\mathrm{Fe} / \mathrm{S}$ protein were measured in parallel samples prior to digitonin fractionation. Enzyme activities and amounts of $\mathrm{Fe} / \mathrm{S}$-protein in pellets $(\mathrm{A})$ and supernatants (B) are expressed as percentages of the total activities. Abbreviations: Adk, adenylate kinase; Fum, fumarase. 


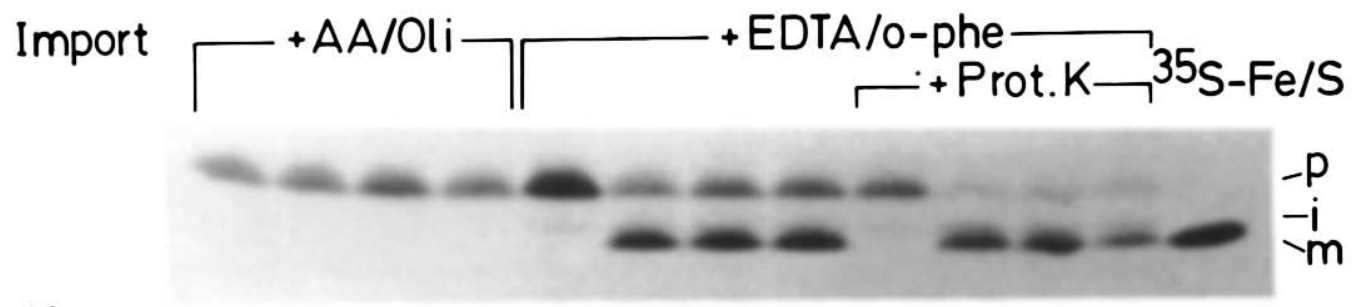

Chase

$\begin{array}{llllllllllllll}\mathrm{AA} / O l i & - & - & + & + & - & - & + & + & - & - & + & + & \\ \mathrm{Val} & - & - & - & + & - & - & - & + & - & - & - & + & \\ \mathrm{Mn} 2+ & - & + & + & + & - & + & + & + & - & + & + & + & \\ & 1 & 2 & 3 & 4 & 5 & 6 & 7 & 8 & 9 & 10 & 11 & 12 & 13\end{array}$

Figure 10. Conversion of Imported $\mathrm{p}-\mathrm{Fe} / \mathrm{S}$ to $\mathrm{m}-\mathrm{Fe} / \mathrm{S}$

Mitochondria were incubated for $30 \mathrm{~min}$ at $25^{\circ} \mathrm{C}$ in reticulocyte lysates containing labeled p-Fe/S. The first group of reactions (lanes 1-4) contained antimycin $A$ and oligomycin, and served as controls for the efficiency of inhibition of the mitochondrial membrane potential. To the second and third groups of reactions (lanes 5-8 and 9-12), EDTA and o-phenanthroline were added to block the matrix peptidase. After import, mitochondria were reisolated and resuspended in SEM buffer containing $0.5 \mathrm{mM}$ o-phenanthroline to maintain the block of the matrix peptidase. Reactions 9-12 were treated with proteinase $\mathrm{K}$ to remove precursor bound to the surface of mitochondria. Following digestion, PMSF was added. Prior to a third incubation, the following additions were made: the third and fourth reactions of each group received antimycin $A$ and oligomycin (lanes $3,4,7,8$, 11, 12); to the fourth reactions $0.5 \mu \mathrm{M}$ valinomycin (Val) was also added (lanes 4, 8, 12). In reactions 2-4 of each group, the block of the matrix peptidase was relieved by the addition of $1 \mathrm{mM} \mathrm{MnCl}$ (lanes 2-4, 6-8 and 10-12). No further addition was made to the first reaction of each group (lanes 1,5 , and 9). All samples were incubated for $20 \mathrm{~min}$ at $25^{\circ} \mathrm{C}$. Mitochondria were then reisolated, and Fe/S protein was immunoprecipitated. The precipitates were separated electrophoretically. A fluorograph of the dried gel is shown. Abbreviations are as in Figure 1.

protein was retained in the mitochondrial membrane fraction, confirming the tight association of this subunit with the complex (Figure 8A). A similar result was observed with $\mathrm{m}-\mathrm{Fe} / \mathrm{S}$ that had been imported into isolated mitochondria under standard conditions (Figure 8A). In sharp contrast, imported p-Fe/S and i-Fe/S were almost completely recovered in the soluble fraction when mitochondria were extracted with buffer containing $0.1 \mathrm{M} \mathrm{NaCl}$ (Figure 8B).

These data taken together show that the imported $\mathrm{p}-\mathrm{Fe} / \mathrm{S}$ and i-Fe/S are water-soluble species and are not tightly associated with membranes. In which of the two aqueous compartments of the mitochondrion are these species located? To answer this question, mitochondria, after having imported precursor proteins, were subfractionated by digitonin treatment. This treatment successively opens the intermembrane space and the matrix space (Schnaitman and Greenawalt, 1968). Adenylate kinase and fumarase were used as enzymatic markers for the mitochondrial intermembrane space and matrix, respectively. As shown in Figure 9, at $0.05 \%-0.075 \%$ digitonin the majority of adenylate kinase activity was found in the supernatant, whereas fumarase activity was retained in the pellet. Imported $\mathrm{p}-\mathrm{Fe} / \mathrm{S}$ and $\mathrm{i}-\mathrm{Fe} / \mathrm{S}$ were released by the digitonin treatment in a fashion very similar to fumarase (Figure 9).

In conclusion, imported p-Fe/S and i-Fe/S are soluble species. They are located in the matrix of the mitochondrion.

Precursor Imported into the Matrix Is on the Native Assembly Pathway

p-Fe/S was imported into mitochondria in the presence of EDTA and o-phenanthroline (Figure 10, lanes 5-12). After reisolation, mitochondria were further incubated under a variety of conditions. If no addition was made during the second incubation, p-Fe/S was preserved, and remained inaccessible to protease (Figure 10, lanes 5 and 9 ). When $\mathrm{Mn}^{2+}$ was present during the second incubation to reactivate the processing peptidase, $\mathrm{m}-\mathrm{Fe} / \mathrm{S}$ was formed, and was also protease-resistant (Figure 10, lanes 6 and 10). When reactivation of the processing peptidase was done in the absence of a membrane potential, i.e., by adding antimycin $A$ and oligomycin (Figure 10, lanes 7 and 11) or by adding the $\mathrm{K}^{+}$ionophore valinomycin in addition to these inhibitors (Figure 10, lanes 8 and 12), m-Fe/S was still formed. This shows that the imported $\mathrm{p}-\mathrm{Fe} / \mathrm{S}$ was beyond the energy-requiring step of the import pathway. The effectiveness of antimycin A and oligomycin in blocking import of the precursor is shown in Figure 10 (lanes 1-4). The data further show that the imported $p-F e / S$ is not a "dead-end" species formed in an artifactual pathway.

As mentioned above, the mature Fe/S protein in the functional complex is on the outer face of the inner membrane. Does the imported p-Fe/S in the matrix, when it is processed to $\mathrm{m}-\mathrm{Fe} / \mathrm{S}$ by reactivation of the processing peptidase, reach the outer face of the inner membrane? To answer this question, $\mathrm{p}-\mathrm{Fe} / \mathrm{S}$ was imported into the matrix and then processed by adding $\mathrm{Mn}^{2+}$ ions. The mitochondria were then subjected to treatment with increasing concentrations of digitonin to successively open intermembrane space and matrix, and the release of marker enzymes was monitored. Afterward, proteinase $k$ was added to determine the sensitivity to protease of the various forms of $\mathrm{Fe} / \mathrm{S}$ protein in the two compartments (Figure 11). Whereas imported p-Fe/S and i-Fe/S were resistant to protease at digitonin concentrations that leave the matrix intact, the $\mathrm{m}$-Fe/S originating from imported 


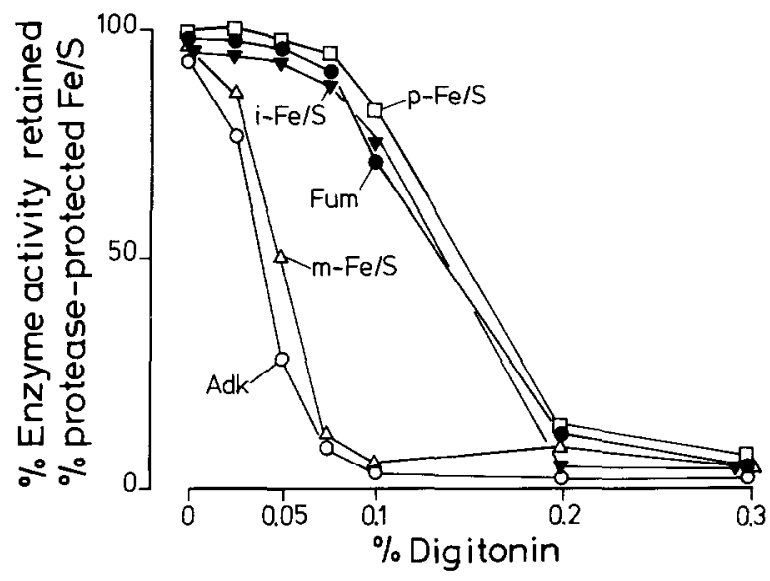

Figure 11. Location of $\mathrm{m}$-Fe/S Produced from Imported $\mathrm{p}$-Fe/S at the Outer Surface of the Inner Mitochondrial Membrane

p-Fe/S-protein was imported in the presence of EDTA and o-phenanthroline. Antimycin A and oligomycin were added, and mitochondria were treated with trypsin as described in Experimental Procedures. After addition of soy bean trypsin inhibitor, the sample was divided; from both halves mitochondria were reisolated by centrifugation and were resuspended in BSA buffer containing $2.5 \mathrm{mM} \mathrm{MgCl}, 4 \mu \mathrm{M}$ antimycin $A$, and $10 \mu \mathrm{M}$ oligomycin. The first aliquot was made $5 \mathrm{mM}$ in EDTA and $0.5 \mathrm{mM}$ in o-phenanthroline to maintain the block of the matrix peptidase. To the second aliquot, $1 \mathrm{mM} \mathrm{MnCl}_{2}$ was added to release the block of the processing peptidase. Both fractions were incubated for $30 \mathrm{~min}$ at $25^{\circ} \mathrm{C}$. Mitochondria were isolated again and were resuspended at a concentration of $10 \mathrm{mg} / \mathrm{ml}$ in SEMK medium containing o-phenanthroline. Digitonin fractionation was carried out as described in Experimental Procedures. After digitonin treatment each reaction was divided into two parts. One part was separated into pellets and supernatants, and aliquots were used for determination of marker enzyme activities (see Figure 9). From the second part, aliquots (corresponding to $20 \mu \mathrm{g}$ of mitochondria) were diluted 3-fold with SEM buffer containing o-phenanthroline. These samples were incubated in the presence of proteinase $\mathrm{K}$, protease activity was blocked by addition of PMSF, and fractions were diluted 7-fold with Triton buffer. Fe/S protein was immunoprecipitated, and the precipitates were electrophoresed. Fluorographs were quantified by densitometry. Data are expressed as a percentage of activity of marker enzymes retained in the mitochondrial pellets after digitonin fractionation, or as a percentage of protease-protected Fe/S protein. Abbreviations are as in Figure 9.

$\mathrm{p}-\mathrm{Fe} / \mathrm{S}$ was sensitive to proteinase $\mathrm{K}$ at concentrations of digitonin sufficient to open the intermembrane space. This suggests that processing of matrix-imported $p-F e / S$ is accompanied by translocation across the inner membrane back to the outer surface.

Fe/S Protein Transported In Vitro via the Mitochondrial Matrix Assumes its Correct Topology and is Assembled with Other Subunits of Complex III The sensitivity to protease of mature, assembled Fe/S protein in mitochondria with opened intermembrane spaces was analyzed. Mitochondria from cells grown in the presence of $\left[{ }^{35}\right.$ S] sulfate were treated with increasing concentrations of digitonin and a fixed concentration of proteinase $\mathrm{K}$. The immunoprecipitated $\mathrm{Fe} / \mathrm{S}$ protein was analyzed by gel electrophoresis. As shown in Figure 12, the more the outer membrane was made permeable by digitonin, the more the assembled $\mathrm{m}$-Fe/S was digested by the protease, resulting in a fragment with a slightly

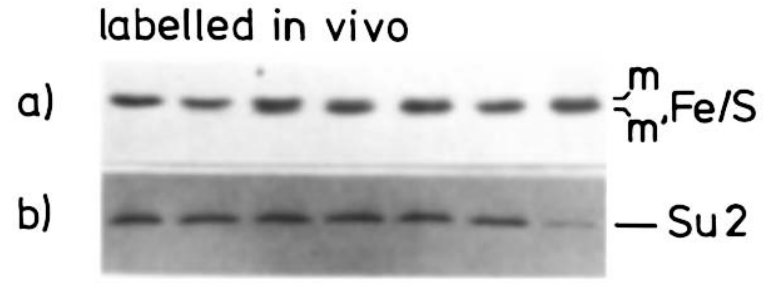

imported in vitro

C)

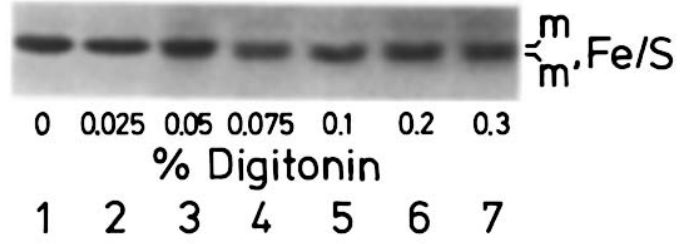

Figure 12. Topology of $\mathrm{m}-\mathrm{Fe} / \mathrm{S}$ in Mitochondria Labeled In Vivo Mitochondria from Neurospora cells labeled in vivo with [ ${ }^{35}$ S]sulfate were incubated for $30 \mathrm{~min}$ at $25^{\circ} \mathrm{C}$ in "cold lysates" (see Experimental Procedures) under conditions corresponding to in vitro import reactions. After reisolation, mitochondria were resuspended in SEMK medium and then subjected to treatment with increasing concentrations of digitonin $(0 \%-0.3 \%$ [w/v]; lanes $1-7)$. They were then incubated with proteinase $\mathrm{K}$. Fe/S-protein (a) and subunit 2 of $F_{1}$ ATPase (b) were immunoprecipitated. For comparison, mitochondria in which $\mathrm{m}-\mathrm{Fe} / \mathrm{S}$ had been produced in vitro from imported $\mathrm{p}-\mathrm{Fe} / \mathrm{S}$ in the absence of a membrane potential were treated under the same conditions (c). Abbreviations: m'Fe/s, fragment of $m-\mathrm{Fe} / \mathrm{S}$; $\mathrm{Su} 2$, subunit 2 of $F_{1}$-ATPase.

lower apparent molecular weight than intact $\mathrm{m}-\mathrm{Fe} / \mathrm{S}$ (Figure 12a). As a control, degradation of ATPase subunit 2 was followed, and disappearance of this protein was only seen when the matrix space was opened (Figure 12b). These data confirm that the assembled $\mathrm{m}$-Fe/S protrudes into the intermembrane space and that it is integrated in such a manner that only a small peptide can be cleaved from the amino or carboxyl terminus. If the mitochondrial membranes were solubilized with Triton X-100, m-Fe/S was completely degraded by the protease concentrations applied in this experiment (not shown).

We assume that this particular pattern of protease sensitivity is a result of the specific arrangement of the $\mathrm{Fe} / \mathrm{S}$ protein in complex III. If the Fe/S protein is imported into the matrix in vitro and then chased to the outer surface of the inner membrane, where it is then assembled in a way simllar to $\mathrm{m}-\mathrm{Fe} / \mathrm{S}$ in vivo, It should dlsplay the same response to protease treatment of digitonin-permeabilized mitochondria. Indeed, this was observed, as shown in Figure 12c. Apparently, $\mathrm{p}$-Fe/S imported in vitro was not only chased to the outer surface of the inner membrane after cleavage, at least part of it also became sensitive to proteolytic attack in a manner that is not distinguishable from the protease sensitivity of $\mathrm{m}$-Fe/S imported and assembled in vivo. It cannot be determined from this study whether processing of i-Fe/S occurs in the matrix and a mature-sized form of $\mathrm{Fe} / \mathrm{S}$ protein is translocated across the inner membrane, or whether processing from i-Fe/S to $\mathrm{m}$-Fe/S occurs on the outside of the inner membrane.

Another indication that imported p-Fe/S can be chased to its functional location at the surface of the inner mem- 
$\%$ of $\mathrm{Fe} / \mathrm{S}$-protein

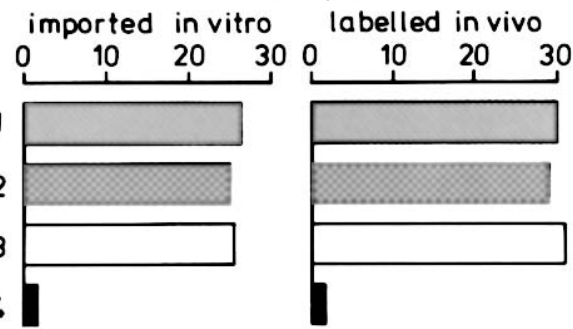

Figure 13. Coprecipitation of $\mathrm{m}-\mathrm{Fe} / \mathrm{S}$ Assembled In Vitro and In Vivo with Cytochrome $c_{1}$ by an Antibody Directed against Cytochrome $c_{1}$ Mitochondria were reisolated after import of precursor proteins in vitro (left) or were isolated from cells grown in the presence of [ ${ }^{35} \mathrm{~S}$ ]sulfate (right). Mitochondrial pellets were resuspended at a concentration of $3.3 \mathrm{mg} / \mathrm{ml}$ in $20 \mathrm{mM}$ Tris-acetate $(\mathrm{pH} 7.0)$ containing $5 \%$ sucrose, $1 \%$ Triton X-100, and 0.1 mM PMSF. After gentle mixing for $2 \mathrm{~min}$ at $4^{\circ} \mathrm{C}$, the samples were each divided into four portions containing $50 \mu \mathrm{g}$ mitochondrial protein and were diluted 15-fold with $20 \mathrm{mM}$ Tris-acetate (pH 7.0) containing 5\% sucrose and $50 \mathrm{mM} \mathrm{NaCl}$. After a clarifying spin at $48,000 \times \mathrm{g}$ for $5 \mathrm{~min}$, a monospecific antiserum against cytochrome $c_{1}$ was added to the first three portions in amounts sufficient to immunoprecipitate all cytochrome $c_{1}$ (rows $1-3$ ). The fourth portions received the same amount of preimmune serum (row 4). The samples were incubated for $45 \mathrm{~min}$ at $0^{\circ} \mathrm{C}$. To portions 3 (row 3) a supernatant from unlabeled mitochondria, produced as above, was added to 10fold (w/w) excess compared with the labeled mitochondria present in the assays. Incubation at $D^{\circ} \mathrm{C}$ was continued for $30 \mathrm{~min}$. Immunecomplexes were harvested by the addition of protein A-Sepharose and were washed three times with $600 \mu \mathrm{l}$ of $20 \mathrm{mM}$ Tris-acetate $(\mathrm{pH} 7.0)$ containing $5 \%$ sucrose and $0.05 \%$ Triton X-100. SDS-containing buffer was added, and the immunecomplexes were dissociated. The second sample of each group (row 2) was diluted 20-fold with Triton buffer, and $\mathrm{Fe} / \mathrm{S}$ protein was reprecipitated with anti-Fe/S antiserum. The dissociated samples were separated by electrophoresis, and fluorographs were quantified by densitometry. Data are expressed as percentages of total $\mathrm{Fe} / \mathrm{S}$ protein precipitated from corresponding aliquots of mitochondria.

brane is that the $\mathrm{m}$-Fe/S formed in this reaction becomes assembled with other subunits of complex III. When mitochondria labeled in vivo were solubilized with Triton $\mathrm{X}-100$ at low salt concentrations, the antibody directed against Fe/S protein coprecipitated a band corresponding to cytochrome $c_{1}$ (not shown). An antibody directed against cytochrome $c_{1}$ coprecipitated a band corresponding to $\mathrm{m}-\mathrm{Fe} / \mathrm{S}$ (Figure 13). The identity of the coprecipitated $\mathrm{Fe} / \mathrm{S}$ protein was verified by solubilization of the immunecomplex in SDS-containing buffer and reprecipilation with anti-Fe/S antibudy. Furthermore, an excess of unlabeled mitochondria (solubilized with Triton X-100) did not cause a reduction in the amount of coprecipitated $\mathrm{Fe} / \mathrm{S}$ protein labeled in vivo. This demonstrates that $\mathrm{Fe} / \mathrm{S}$ protein was immunoprecipitated only as a complex with cytochrome $\mathrm{c}_{1}$

When the same experiment was performed with mitochondria after they had imported $\mathrm{Fe} / \mathrm{S}$ protein in vitro, essentially the same result was observed, suggesting that assembly of $\mathrm{Fe} / \mathrm{S}$-protein with cytochrome $c_{1}$ in vitro had occurred (Figure 13). This assembly is very likely to occur after processing of Fe/S protein, since p-Fe/S and i-Fe/S accumulated in the matrix could not be coprecipitated with an antibody against cytochrome $c_{1}$.

In summary, these data suggest that import in vitro
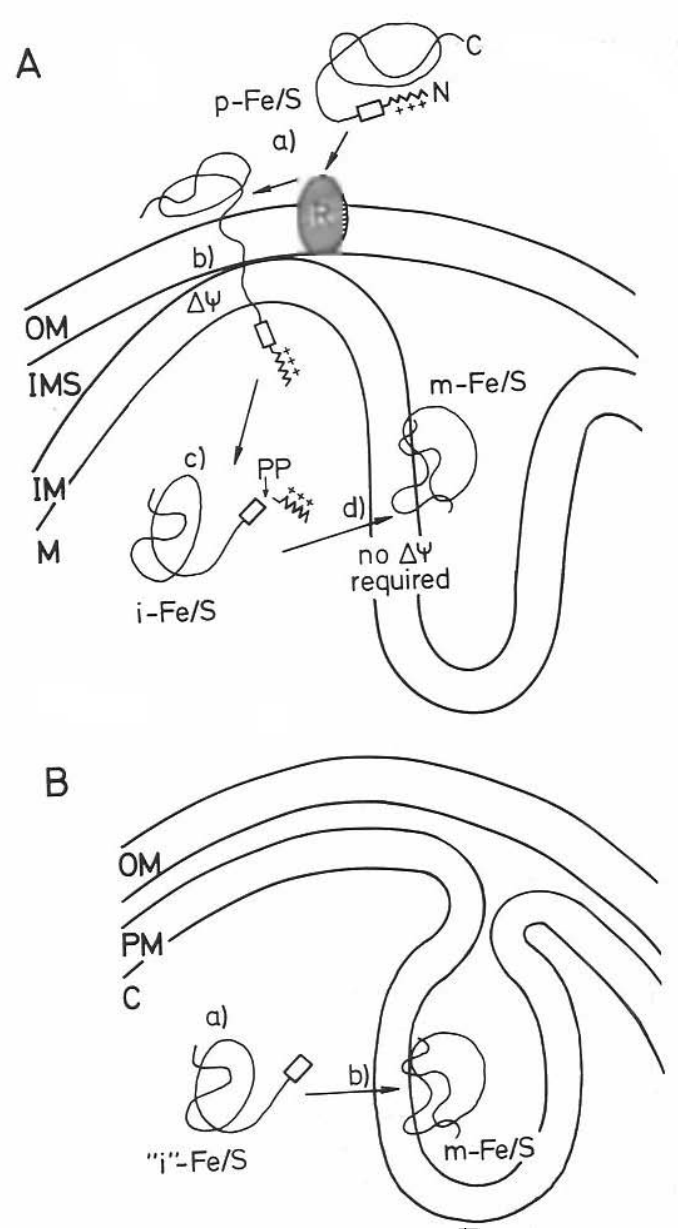

Figure 14. Hypothetical Transport and Assembly Pathways of Fe/S Proteins of Mitochondrial and Bacterial bc $c_{1}$ Complexes

(A) Mitochondria. After specific interaction with proteinaceous structures on the surface of mitochondria (a), p-Fe/S is translocated across translocation contact sites (b) into the mitochondrial matrix (c). There, the matrix targetting sequence is cleaved off by the processing peptidase, and $\mathrm{i}-\mathrm{Fe} / \mathrm{S}$ is generated. $\mathrm{i}-\mathrm{Fe} / \mathrm{S}$ is redirected across the inner membrane, and $\mathrm{m}$-Fe/S is formed (d). Abbreviations: OM, outer membrane; IMS, intermembrane space; IM, inner membrane; $M$, matrix; $R$, receptor; PP, processing peptidase; $\Delta \varphi$, membrane potential.

(B) R. sphaeroides. Fe/S protein is synthesized as a precursor about $1-2$ kd larger than the mature protein $\left("{ }^{n}{ }^{n}-\mathrm{Fe} / \mathrm{S}\right)(\mathrm{a})$. This " $\mathrm{i}^{\mathrm{n}}-\mathrm{Fe} / \mathrm{S}$ is translocated from the cytoplasm across the photosynthetic membrane and then processed to $\mathrm{m}-\mathrm{Fe} / \mathrm{S}$ (b). Abbreviations: OM, outer membrane; $\mathrm{PM}$, plasma membrane; $\mathrm{C}$, cytoplasm.

faithfully reflects the physiological import pathway and that the various intermediates analyzed in this study are indeed intermediates in the native assembly pathway.

\section{Discussion}

A hypothetical assembly pathway for the Rieske Fe/Sprotein, as it emerges from our data, is depicted in Figure 14A. In a first step, the precursor appears to interact with receptors on the mitochondrial surface. Very mild protease treatment of mitochondria completely abolished import of p-Fe/S (not shown), as we have previously described for a number of other imported proteins (Zwizinski 
et al., 1984). In a reaction following the initial binding to proteinaceous receptors, $\mathrm{p}-\mathrm{Fe} / \mathrm{S}$ is translocated through the outer and inner mitochondrial membranes via translocation contact sites. This reaction occurs only in the presence of a membrane potential. The precursor is completely imported into the mitochondrial matrix, where processing then occurs by the metal-dependent processing peptidase to yield i-Fe/S. It is possible that this proteolytic processing takes place as soon as the amino terminus of $\mathrm{p}-\mathrm{Fe} / \mathrm{S}$ enters the matrix space, while a major part of the polypeptide is still on its way through the membrane; however, completion of translocation across the contact sites apparently does occur. The i-Fe/S formed then has the ability to recross the inner membrane in the opposite direction. The role of the eight amino acid extension of $\mathrm{i}-\mathrm{Fe} / \mathrm{S}$ in this process is unclear so far. It remains to be determined exactly when and where i-Fe/S is processed to $\mathrm{m}-\mathrm{Fe} / \mathrm{S}$, and, possibly in connection with this reaction, where and how the Fe/S center is formed. Translocation back across the inner membrane does not appear to require a membrane potential. The $\mathrm{m}-\mathrm{Fe} / \mathrm{S}$ then occupies its specific location at the outer surface of the inner membrane, and it is then assembled with other subunits of complex III, in particular with cytochrome $c_{1}$. The Fe/S protein does not seem to be deeply embedded in the lipid phase of the inner membrane since it can be extracted from the membrane with $0.1 \mathrm{M}$ sodium carbonate. It can also be selectively released from the complex by mild detergent treatment; after such removal it can be easily rebound to restore an active complex (Trumpower, 1981). The precise arrangement of the polypeptide chain remains unclear so far, but it seems quite reasonable to assume that the hydrophobic stretch in the polypeptide chain (amino acids 62 to 86 in Neurospora [Harnisch et al., 1985]) may mediate hydrophobic interaction with other subunits rather than forming an anchor of the type that integrates proteins such as glycophorin or histocompatibility antigens into the plasma membrane (Tomita and Marchesi, 1975; Ploegh et al., 1981). The possibility cannot be excluded, however, that $\mathrm{m}-\mathrm{Fe} / \mathrm{S}$ spans the membrane and is shielded from direct lipid contact by other subunits of the $b c_{1}$ complex. In any case, the major hydrophilic portion of the molecule is exposed toward the intermembrane space and must be translocated across the inner membrane from the matrix side.

At first glance the assembly pathway proposed in Figure 14A seems unnecessarily complex. For the sake of simplicity, one might be inclined to predict a pathway in which the major part of the precursor has only to cross the outer membrane to reach its functional location. What could be the reason for this apparent complexity?

Data are available on the structure and function of chloroplast and bacterial proteins that are equivalent to the mitochondrial Rieske Fe/S protein. The Fe/S protein of the cytochrome $b c_{1}$ complex of $R$. sphaeroides has been cloned recently, and the gene has been sequenced (Gabellini and Sebald, 1986). A striking homology of the $\mathrm{Fe} / \mathrm{S}$ protein of this prokaryote to the Neurospora $\mathrm{Fe} / \mathrm{S}$ protein has been observed. The function of the R. sphaeroides $\mathrm{Fe} / \mathrm{S}$ protein is directly comparable to that of the mitochondrial Fe/S protein, since it is part of a bc $c_{1}$ complex and transfers electrons to cytochrome $c_{1}$ (Trumpower, 1981; Hauska et al., 1983). The R. sphaeroides and mitochondrial cytochromes $c_{1}$ display a remarkable homology. Moreover, the hydropathy plots of the $\mathrm{Fe} / \mathrm{S}$ proteins (and of the respective cytochrome $c_{1}$ species) suggest that their spatial structures are essentially the same (Gabellini and Sebald, 1986). Also, the topology of the $\mathrm{Fe} / \mathrm{S}$ protein (and of cytochrome $c_{1}$ ) appears to be the same in both cases: the $F_{\theta} / S$ protein is on the opposite side of the $F_{1}$-ATPase, i.e., facing the intermembrane space in mitochondria and facing the thylakoid lumen in photosynthetic bacteria. As judged from all available data, the function, topology, and structure of the Fe/S proteins in the mitochondrial bc ${ }_{1}$ complex, the bacterial $\mathrm{bc}_{1}$ complex, and the chloroplast $b_{6} f$ complex are directly comparable (Hauska et al., 1983)

In R. sphaeroides the $\mathrm{Fe} / \mathrm{S}$ protein is synthesized on the ribosomes in the bacterial cytoplasm, and it must be eventually transferred across the photosynthetic membrane to its inner face (Figure 14B). The bacterial Fe/S protein does not have a presequence comparable to that of the mitochondrial proteins; however, a slight reduction in apparent molecular weight upon assembly has been reported, which could be equivalent to the change from $\mathrm{i}-\mathrm{Fe} / \mathrm{S}$ to $\mathrm{m}$-Fe/S noted here (Gabellini et al., 1985). In light of the endosymbiotic hypothesis of mitochondrial origin, it seems reasonable to assume that the mitochondrial $\mathrm{Fe} / \mathrm{S}$ protein is a component whose gene has been transferred from the endosymbiont to the nucleus of the host cell. The function of the protein, its primary structure, its folding into the three-dimensional structure, and its topology, however, have been conserved.

On the basis of these considerations, we want to suggest the following explanation for the assembly pathway: After transfer of the gene to the host nucleus, the Fe/S protein had to be translocated across both mitochondrial membranes back into the matrix space. For this purpose, in the eukaryotic cell a positively charged presequence was added to the Fe/S protein, and translocation contact sites were introduced to allow direct passage of precursors into the matrix. When the precursor has then reached the matrix and the presequence is cleaved off, it can enter its "ancestral" transport pathway, which is translocation from the mitochondrial matrix (the equivalent of the bacterial cytosol) across the inner mitochondrial membrane (the equivalent of the bacterial plasma membrane) (Figure 14B). We find it particularly attractive to propose that proteins whose primary structure, folding, topology, and function have been conserved throughout evolution should also have conserved assembly pathways or folding pathways. A given folding pathway resulting from a certain primary structure probably cannot be simply changed in such a manner that a protein can now be inserted into a membrane from the opposite side, ending up in the original topological arrangement. We find it much easier to conceive that after gene transfer, a quite general pathway for many proteins has been invented to get them back on their ancestral folding and assembly pathways. Indeed, available evidence suggests that the basic import path- 
ways of proteins into the matrix of mitochondria are rather uniform. Thus, the assembly pathway described here appears much less complicated than it would appear from the simple idea that the $\mathrm{Fe} / \mathrm{S}$ protein has to be transported across only the outer membrane. We predict that this "conservative sorting" hypothesis applies to many other mitochondrial proteins. Indeed, preliminary experiments suggest that a complete transfer of the precursor to subunit 9 of $F_{0} F_{1}$-ATPase (proteolipid) into the matrix space occurs before insertion into the inner membrane.

On the other hand, we suggest that some proteins are exceptions. For instance, cytochrome $\mathrm{c}$, which would be predicted to behave essentially in the same manner as the $\mathrm{Fe} / \mathrm{S}$ protein, may now be imported by a "new" pathway that circumvents import into the matrix. As a matter of fact, cytochrome $\mathrm{c}$ is quite exceptional in that it does not have a cleavable presequence, is not translocated across contact sites, and does not require a membrane potential for import (Korb and Neupert, 1978; Hennig and Neupert, 1981; Hennig et al., 1983). Accordingly, some proteins may have acquired the ability to reach the intermembrane space only by crossing the outer membrane, whereas others, such as the Rieske $\mathrm{Fe} / \mathrm{S}$ protein, contain remnants of ancestral mechanisms within their import pathways.

For cytochrome $c_{1}$, a polypeptide that is integrated into the inner membrane and has a large hydrophilic domain that protrudes into the intermembrane space, a different pathway of intramitochondrial sorting has been proposed based on gene fusion experiments (van Loon et al., 1986; Hurt and van Loon, 1986). When the complete presequence of cytochrome $c_{1}$ was fused to dihydrofolate reductase, the passenger protein was found in the intermembrane space upon import into mitochondria. When the second part of the presequence (consisting of 19 uncharged amino acids followed by two acidic residues) was deleted, dihydrofolate reductase was found in the matrix. The authors assume that this part of the amino-terminal extension could function as a "stop-transfer" sequence, which prevents the precursor from being completely translocated across the inner membrane. This would allow only the first part of the presequence (the so called matrix-targeting sequence) to reach the matrix and be cleaved of by the processing peptidase. A similar pathway has been proposed for the assembly of the intermembrane-space enzymes cytochrome c peroxidase (Kaput et al., 1982) and cytochrome $b_{2}$ (Guiard, 1985). So far, only end points but not intermediates of the proposed import pathways have been documented, and experiments are therefore necessary to prove or disprove this hypothesis. It has not been excluded that the hydrophobic part of the presequence (e.g., in cytochrome c peroxidase) may act as a second targeting signal redirecting a polypeptide that has been completely imported into the matrix back across the inner membrane.

\section{Experimental Procedures}

\section{Isolation of Mitochondria}

Neurospora crassa wild-type strain 74A was grown as previously described (Teintze et al., 1982), and hyphae were harvested by filtration. All of the following operations were carried out at $4^{\circ} \mathrm{C}$. Hyphae $(1 \mathrm{~g})$ were ground for $1 \mathrm{~min}$ in a mortar with $1.5 \mathrm{~g}$ of quartz sand and $1 \mathrm{ml}$ of Percoll buffer ( $30 \%$ [ $\mathrm{V} / \mathrm{V}$ ] Percoll, $180 \mathrm{mM} \mathrm{KCl,} 3 \%$ bovine serum albumin, $1 \mathrm{mM}$ EDTA, and $10 \mathrm{mM}$ Mops adjusted to $\mathrm{pH} 7.2$ with $\mathrm{KOH}$ ) containing $0.2 \mathrm{mM}$ phenylmethylsulfonyl fluoride (PMSF). After addition of another $2 \mathrm{ml}$ of Percoll buffer, grinding was continued for $2 \mathrm{~min}$ further. The slurry was centrifuged twice for $5 \mathrm{~min}$ at $1,200 \times \mathrm{g}$ in a JA-20 rotor, and the pellet was discarded. The resulting supernatant was spun for $15 \mathrm{~min}$ at $165,000 \times \mathrm{g}$ in a Beckman Ti50 rotor. Mitochondria were collected as a sharp band from the dense portion of the gradient formed during centrifugation. The fraction obtained was washed once with SEM medium (0.25 $\mathrm{M}$ sucrose, $1 \mathrm{mM}$ EDTA, and $10 \mathrm{mM}$ Mops [ $\mathrm{pH}$ 7.2]) and was resuspended in SEM at a protein concentration of $5 \mathrm{mg} / \mathrm{ml}$. ${ }^{35} \mathrm{~S}$-labeled mitochondria were isolated from hyphae grown in the presence of $\left[{ }^{35} \mathrm{~S}\right]$ sulfate as described by Teintze et al. (1982).

\section{Import of Fe/S Protein In Vitro}

[ ${ }^{35}$ S]methionine-labeled $p$-Fe/S was synthesized in rabbit reticulocyte lysates programmed with Neurospora poly $(A)^{+}$RNA (Pelham and Jackson, 1976) as previously described by Schleyer et al. (1982). To obtain "cold lysates," the lysates were treated with nuclease as usual, but $\left[{ }^{35}\right.$ S]methionine and mRNA were omitted and lysates were not incubated for protein synthesis. Postribosomal supernatants were prepared and supplemented according to Zimmermann and Neupert (1980). Lysates were stored in aliquots at $-80^{\circ} \mathrm{C}$. Prior to use, lysates were thawed at $25^{\circ} \mathrm{C}$, and mitochondria were added for import (incubation for $30 \mathrm{~min}$ at $25^{\circ} \mathrm{C}$ ). Import mixtures usually contained $2 \mathrm{mM}$ $\mathrm{NADH}$. In certain experiments (as indicated in the Figure legends) incubation was carried out in lysates diluted with BSA buffer, which consists of $3 \%$ bovine serum albumin (Sigma), $220 \mathrm{mM}$ sucrose, $70 \mathrm{mM}$ $\mathrm{KCl}$, and $10 \mathrm{mM}$ Mops adjusted to $\mathrm{pH} 7.2$ with $\mathrm{KOH}$. For inhibition of the matrix-localized processing peptidase, $5 \mathrm{mM}$ EDTA and $0.1 \mathrm{mM}$ 1,10-phenanthroline (Schmidt et al., 1984) were added, from 250 and $20 \mathrm{mM}$ stock solutions, respectively. Where indicated, import of precursors was prevented by a combination of antimycin $A$ and oligomycin (4 $\mu \mathrm{M}$ and $10 \mu \mathrm{M}$ final concentrations, respectively, added from 100fold concentrated stock solutions in ethanol). Control samples received the same volumes of inhibitor-free solutions. Following incubation for import, mitochondria were reisolated by centrifugation and were resuspended in SEM buffer. Proteinase $\mathrm{K}(15 \mu \mathrm{g} / \mathrm{ml}$ final concentration) or trypsin (final concentration $10 \mu \mathrm{g} / \mathrm{ml}$ ) was added, and the samples were incubated for $30 \mathrm{~min}$ at $0^{\circ} \mathrm{C}$. Proteinase $\mathrm{K}$ activity was stopped by the addition of PMSF ( $1 \mathrm{mM}$ final concentration); trypsin activity was stopped by a 30 -fold excess ( $w / w)$ of soy bean trypsin inhibitor. Incubation was continued for $5 \mathrm{~min}$ at $0^{\circ} \mathrm{C}$

\section{Subfractionation of Mitochondria}

Alkaline treatment of mitochondria was carried out essentially as described by Fujiki et al. (1982). Immunoprecipitation from samples containing $100 \mathrm{mM} \mathrm{Na}_{2} \mathrm{CO}_{3}$ was done after addition of Triton X-100 (1\% final concentration) and neutralization to $\mathrm{pH} 7.4$ with $200 \mathrm{mM}$ $\mathrm{NaH}_{2} \mathrm{PO}_{4}$. To determine the solubility of imported $\mathrm{Fe} / \mathrm{S}$ protein species, mitochondria were sonicated at $0^{\circ} \mathrm{C}-4^{\circ} \mathrm{C}$ (Branson sonifier with top end microtip, setting 2, pulsed, $20 \%$ duty, twice for 1 min with a 1 min cooling interval) in the presence of different salt concentrations in SEM buffer. Samples were centrifuged for $1 \mathrm{hr}$ at $165,000 \times \mathrm{g}$ in a Ti50 rotor, and the resulting pellets and supernatants were analyzed by immunoprecipitation (see below).

In localization experiments, mitochondria were subfractionated as follows. After reisolation, mitochondria were resuspended to a concentration of $10 \mathrm{mg} / \mathrm{ml}$ in SEMK medium (SEM buffer containing $100 \mathrm{mM}$ $\mathrm{KCl}$ ). Cytosolic proteinase inhibitor from N. crassa (Schmidt et al., 1984) was added $(0.5 \mathrm{mg} / \mathrm{ml}$ final concentration). Digitonin (Merck, Darmstadt), recrystallized from hot ethanol, was dissolved in SEMK medium (dilutions ranging between $0 \%$ and $1 \%$ were made from the same stock solution) and was added to the final concentrations indicated in the Figures. Samples (final volume of $20 \mu$ ) contained $100 \mu \mathrm{g}$ of mitochondrial protein. After $1 \mathrm{~min}$ at $0^{\circ} \mathrm{C}$, samples were diluted 7-fold with SEMK medium. Aliquots corresponding to $25 \mu \mathrm{g}$ of untreated mitochondria were diluted 3-fold with SEM buffer, treated with proteinase $K$ as described above, and immunoprecipitated. The remaining parts of the samples were centrifuged for $20 \mathrm{~min}$ at $48000 \times \mathrm{g}$. Activities of adenylate kinase and fumarase in pellets and supernatants were determined as reported previously (Schmidt et al., 1984). 
Immunoprecipitation

Routinely, the samples were transferred into new Eppendorf tubes, and mitochondria were reisolated by centrifugation for $12 \mathrm{~min}$ at 12,000 $\times \mathrm{g}$. The pellets were dissolved in SDS-containing buffer (Schleyer et al., 1982) and diluted with Triton buffer $(1 \%$ Triton $X-100,0.3 \mathrm{M} \mathrm{NaCl}$ $5 \mathrm{mM}$ EDTA, and $10 \mathrm{mM}$ Tris-HCl [pH 7.4]) (Zimmermann and Neupert, 1980). Where indicated, samples were solubitized directly in Triton buffer containing $0.1 \mathrm{mM}$ PMSF. Antisera (directed against $\mathrm{Fe} / \mathrm{S}$ protein, cytochrome $c_{1}$ [Teintze et al., 1982], or subunit 2 of $F_{1}$-ATPase [Zwizinski and Neupert, 1983]) and protein A-Sepharose (Pharmacia) were added in sufficient amounts according to serum titer. Incubations with antibody and protein A-Sepharose were for $1 \mathrm{hr}$ each at $0^{\circ} \mathrm{C}$. The protein A-Sepharose beads were washed and dissociated as previously described (Schleyer et al., 1982).

\section{Miscellaneous}

Protein concentration was determined by the method of Bradford (1976). Electrophoretic separation was carried out on $17 \%$ polyacrylamide gels as described by Laemmli (1970). For fluorography, gels were incubated for $1 \mathrm{hr}$ in Amplify (Amersham) and were exposed to Kodak X-Omat AR fllms at $-80^{\circ} \mathrm{C}$. Isolation of proteins for solld-phase Edman degradation and mitochondria-free processing of $\mathrm{p}-\mathrm{Fe} / \mathrm{S}$ followed the procedure described earlier (Schmidt et al., 1984) except that a purified preparation of processing peptidase (Hawlitschek and Neupert, unpublished data) was used instead of mitochondrial extracts.

\section{Acknowledgments}

We are grateful to Sigrun Meier for excellent technical assistance. We thank Gerhard Hawlitschek for supplying purified processing peptidase, and Dr. Don Nicholson for critically reading the manuscript. The help of Manfred Dünnwald in preparing the Figures and of Sigrun Prommersberger in typing the manuscript is greatly appreciated. This work was supported by the Deutsche Forschungsgemeinschaft (Grant Ne101/19-2) and the Fonds der Chemischen Industrie.

The costs of publication of this article were defrayed in part by the payment of page charges. This article must therefore be hereby marked "advertisement" in accordance with 18 U.S.C. Section 1734 solely to indicate this fact.

Received July 28, 1986; revised September 25, 1986.

\section{References}

Beinert, H., and Albracht, S. P. J. (1982). New insights, ideas and unanswered questions concerning iron-sulfur clusters in mitochondria. Biochim. Biophys. Acta 683, 245-277.

Bell, R. L., Sweetland, J., Ludwig, B., and Capaldi, R. A. (1979). Labelling of complex III with $\left[{ }^{35}\right.$ S]diazobenzene sulfonate: orientation of this electron transfer segment in the mitochondrial inner membrane. Proc. Natl. Acad. Sci. USA 76, 741-745.

Böhni, P., Gasser, S., Leaver, C., and Schatz, G. (1980). A matrixlocalized mitochondrial protease processing cytoplasmically-made precursors to mitochondrial proteins. In The Organization and Expression of the Mitochondrial Genome, A. M. Kroon and C. Saccone, eds. (Amsterdam: Elsevier/North-Holland), pp. 432-433.

Bradford, M. M. (1976). A rapid and sensitive method for the quantitation of microgram quantities of protein utilizing the principle of proteindye binding. Anal. Biochem. 72, 248-254.

Conboy, J. G., Fenton, W. A., and Rosenberg, L. E. (1982). Processing of pre-ornithine transcarbamylase requires a zInc-dependent protease localized to the mitochondrial matrix. Biochem. Biophys. Res. Commun. 105, 1-7.

Daum, G., Gasser, S. M., and Schatz, G. (1982). Import of proteins into mitochondria. Energy-dependent, two-step processing of the intermembrane space enzyme cytochrome $b_{2}$ by isolated yeast mitochondria. J. Biol. Chem. 257, 13075-13080.

Dowhan, W., Bibus, C. R., and Schatz, G. (1985). The cytoplasmicallymade subunit IV is necessary for assembly of cytochrome c oxidase in yeast. EMBO J. 4, 179-184.

Dumont, M. E., and Richards, F. M. (1984). Insertion of apocytochrome $c$ into lipid vesicles. J. Biol. Chem. 259, 4147-4156.
Edwards, C. A., Bowyer, J. R., and Trumpower, B. L. (1982). Function of the iron-sulfur protein of the cytochrome $b-c_{1}$ segment in electron transfer reactions of the mitochondrial respiratory chain. J. Biol. Chem. 257, 3705-3713

Fujiki, Y., Hubbard, A. L., Fowler, S., and Lazarow, P. B. (1982). Isolation of intracellular membranes by means of sodium carbonate treatment: application to endoplasmic reticulum. J. Cell Biol. 93, 97-102.

Gabellini, N., and Sebald, W. (1986). Nucleotide sequence and transcription of the tbc operon from Rhodopseudomonas sphaeroides. Evaluation of the deduced amino acid sequences of the $\mathrm{FeS}$ protein, cytochrome $b$ and cytochrome $c_{1}$. Eur. J. Biochem. 154, 569-579.

Gabellini, N., Harnisch, U., McCarthy, J. E. G., Hauska, G., and Sebald, $W$. (1985). Cloning and expression of the fbc operon encoding the FeS protein, cytochrome $b$ and cytochrome $c_{1}$ from Rhodopseudomonas sphaeroides $b / c_{1}$ complex. EMBO J. 4, 549-553.

Gasser, S. M., Daum, G., and Schatz, G. (1982a). Import of proteins into mitochondria. Energy-dependent uptake of precursors by isolated mitochondria. J. Biol. Chem. 257, 13034-13041.

Gasser, S. M., Ohashi, A., Daum, G., Boehni, P. C., Gibson, J., Reid G. A., Yonetani, T., and Schatz, G. (1982b). Imported mitochondrial proteins cytochrome $b_{2}$ and cytochrome $c_{1}$ are processed in two steps. Proc. Natl. Acad. Sci. USA 79, 267-271.

Guiard, B. (1985). Structure, expression and regulation of a nuclear gene encoding a mitochondrial protein: the yeast $L(+)$-lactate cytochrome c oxidoreductase (cytochrome $b_{2}$ ). EMBO J. 4, 3265-3272.

Hallermayer, G., Zimmermann, R., and Neupert, W. (1977). Kinetic studies on the transport of cytoplasmically synthesized proteins into the mitochondria in intact cells of Neurospora crassa. Eur. J. Biochem. 81, 523-532.

Harmey, M. A., and Neupert, W. (1985). Intracellular transfer of mitochondrial membrane proteins. In The Enzymes of Biological Membranes, Vol. 4, A. Martonosi, ed. (New York: Plenum Press), pp. 431-464.

Harnisch, U., Weiss, H., and Sebald, W. (1985). The primary structure of the iron-sulfur subunit of ubiquinol-cytochrome $c$ reductase from Neurospora, determined by cDNA and gene sequencing. Eur. J. Biochem. 149, 95-99.

Hauska, G., Hurt, E., and Lockau, W. (1983). Comparative aspects of quinol-cytochrome c/plastocyanin oxidoreductases. Biochim. Blophys. Acta 726, 97-133.

Hay, R., Böhni, P., and Gasser, S. (1984). How mitochondria import proteins. Biochim. Biophys. Acta 779, 65-87.

Hennig, B., and Neupert, W. (1981). Assembly of cytochrome c: apocytochrome $\mathrm{c}$ is bound to specific sites on mitachondria before its conversion to holocytochrome C. Eur. J. Biochem. 121, 203-212.

Hennig, B., Köhler, H., and Neupert, W. (1983). Receptor sites involved in posttranslational transport of apocytochrome $\mathrm{c}$ into mitochondria: specificity, affinity and number of sites. Proc. Natl. Acad. Sci. USA 80 , 4963-4967.

Horwich, A. L., Kalousek, F., Mellman, I., and Rosenberg, L. E. (1985). A leader peptide is sufficient to direct mitochondrial import of a chimeric protein. EMBO J. 4, 1129-1135.

Horwich, A. L., Kalousek, F., Fenton, W. A., Pollock, R. A., and Rosenberg, L. E. (1986). Targeting of pre-ornithine transcarbamylase to mitochondria: definition of critical regions and residues in the leader peptide. Cell 44, 451-459.

Hurt, E. C., Pesold-Hurt, B., and Schatz, G. (1984a). The cleavable prepiece of an imported mitochondrial protein is sufficient to direct cytosolic dihydrofolate reductase into the mitochondrial matrix. FEBS Lett. 178, 306-310.

Hurt, E. C., Pesold-Hurt, B., and Schatz, G. (1984b). The aminoterminal region of an imported mitochondrial precursor polypeptide can direct cytoplasmic dihydrofolate reductase into the mitochondrial matrix. EMBO J. 3, 3149-3156.

Hurt, E. C., and van Loon, A. P. G. M. (1986). How proteins find mitochondria and intramitochondrial compartments. Trends Biochem. Sci. 11, 204-207.

Kaput, J., Goltz, S., and Blobel, G. (1982). Nucleotide sequence of the yeast nuclear gene for cytochrome $c$ peroxidase precursor. Functional 
implications of the pre-sequence for protein transport into mitochondria. J. Biol. Chem. 257, 15054-15058.

Karlsson, B., Hovmölier, S., Weiss, H., and Leonard, K. (1983). Structural studies of cytochrome reductase. Subunit topography determined by electron microscopy. J. Mol. Biol. 165, 287-302.

Kolansky, D. M., Conboy, J. G., Fenton, W. A., and Rosenberg, L. (1982) Energy-dependent translocation of the precursor of ornithine transcarbamylase by isolated rat liver mitochondria. J. Biol. Chem. 257, 84678471.

Korb, H., and Neupert, W. (1978). Biogenesis of cytochrome c, transfer to mitochondria and conversion to holocytochrome $\mathrm{c}$. Eur. J. Biochem. 91, 609-620.

Laemmli, U. K. (1970). Cleavage of structural proteins during the assembly of the head of bacteriophage T4. Nature 227, 680-685.

Lewin, A. S., and Norman, D. K. (1983). Assembly of $F_{1}$-ATPase in isolated mitochondria. J. Biol. Chem. 258, 6750-6755

Li, Y., Leonard, W., and Weiss, H. (1981a). Membrane-bound and water-soluble cytochrome $\mathrm{c}_{1}$ from Neurospora mitochondria. Eur. J. Biochem. 116, 199-205.

Li, Y., de Vries, S., Leonard, W., and Weiss, H. (1981b). Topography of the iron-sulfur subunit in mitochondrial ubiquinol:cytochrome $\mathrm{c}$ reductase. FEBS Lett. 135, 277-280.

McAda, P., and Douglas, M. G. (1982). A neutral metallo-endoprotease involved in the processing of an $F_{1}$-ATPase subunit precursor in mitochondria. J. Biol. Chem. 257, 3177-3182.

Miura, S., Mori, M., Amaya, Y., and Tatibana, M. (1982). A mitochondrial protease that cleaves the precursor of ornithine carbamoyl transferase. Eur. J. Biochem. 122, 641-647.

Ohashi, A., Gibson, J., Gregor, I., and Schatz, G. (1982). Import of proteins into mitochondria. The precursor of cytochrome $c_{1}$ is processed in two steps, one of them heme-dependent. J. Biol. Chem. 257, 13042-13047.

Pelham, H. R. B., and Jackson, R. J. (1976). An efficient mRNAdependent translation system from reticulocyte lysates. Eur. J. Biochem. 67, 247-256.

Pfanner, N., and Neupert, W. (1985). Transport of proteins into mitochondria: a potassium diffusion potential is able to drive the import of ADPIATP carrier. EMBO J. 4, 2819-2825.

Ploegh, H. L., Orr, H. T., and Strominger, J. L. (1981). Major histocompatibility antigens: the human (HLA-A, $-B,-C)$ and murine $(H-2 K, H-2 D)$ class I molecules. Cell 24, 287-299.

Rieske, J. S. (1976). Composition, structure, and function of complex III of the respiratory chain. Biochim. Biophys. Acta 456, 195-245.

Sadler, J., Suda, K., Schatz, G., Kaudewitz, F., and Haid, A. (1984). Sequencing of the nuclear gene for the yeast cytochrome $c_{1}$ precursor reveals an unusually complex amino-terminal presequence. EMBO J. 9, 2137-2143.

Schatz, G. (1979). How mitochondria import proteins from the cytoplasm. FEBS Lett. 103, 203-211.

Schleyer, M., and Neupert, W. (1985). Transport of proteins into mitochondria: translocation intermediates spanning contact sites between outer and inner membranes. Cell 43, 339-350.

Schleyer, M., Schmidt, B., and Neupert, W. (1982). Requirement of a membrane potential for the posttranslational transfer of proteins into mitochondria. Eur. J. Biochem. 125, 109-116.

Schmidt, B., Hennig, B., Zimmermann, R., and Neupert, W. (1983). Biosynthetic pathway of mitochondrial ATPase subunit 9 in Neu rospora crassa. J. Cell Biol. 96, 248-255.

Schmidt, B., Wachter, E., Sebald, W., and Neupert, W. (1984). Processing peptidase of Neurospora mitochondria. Two-step cleavage of $1 \mathrm{~m}$ ported ATPase subunit 9. Eur. J. Biochem. 144, 581-588.

Schnaitman, C. A., and Greenawalt, J. W. (1968). Enzymatic properties of the inner and outer membranes of rat liver mitochondria. J. Cell Biol. $38,158-175$.

Sidhu, A., and Beattie, D. S. (1983). Kinetics of assembly of complex III into the yeast mitochondrial membrane. Evidence for a precursor to the iron-sulfur protein. J. Biol. Chem. 258, 10649-10656.

Taniuchi, H., Basile, G., Taniuchi, M., and Veloso, D. (1983). Evidence for formation of two thioether bonds to link heme to apocytochrome $c$ by partially purified cytochrome c synthetase. J. Biol. Chem. 258, 10963-10966.

Teintze, M., Slaughter, M., Weiß, H., and Neupert, W. (1982). Biogenesis of mitochondrial ubiquinol: cytochrome $\mathrm{c}$ reductase (cytochrome bc $_{1}$ complex). J. Biol. Chem. 257, 10364-10371

Tomita, M., and Marchesi, V. T. (1975). Amino-acid sequence and oligosaccharide attachment sites of human erythrocyte glycophorin. Proc. Nall. Acad. Sci. USA 72, 2964-2968.

Trumpower, B. L. (1981). Function of iron-sulfur protein of the cytochrome b- $c_{1}$ segment in electron-transfer and energy-conserving reactions of the mitochondrial respiratory chain. Biochim. Biophys. Acta 639, 129-155.

van Loon, A. P. G. M., and Young, E. T. (1986). Intracellular sorting of alcohol dehydrogenase isoenzymes in yeast: a cytosolic location reflects absence of an amino-terminal targeting sequence for the mitochondrion. EMBO J. 5, 161-165.

van Loon, A. P. G. M., Brändli, A. W., and Schatz, G. (1986). The presequences of two imported mitochondrial proteins contain information for intracellular and intramitochondrial sorting. Cell 44, 801-812.

von Jagow, G., and Sebald, W. (1980). b-Type cytochromes. Ann. Rev. Biochem. 49, 281-314.

Wachter, E., Machleidt, W., Hofner, $H_{\text {., }}$ and Otto, J. (1973). Aminopropyl glass and its p-phenylene diisothiocyanate derivates, a new support in solid-phase Edman degradation of peptides and proteins. FEBS Lett. 35, 97-102.

Zimmermann, R., and Neupert, W. (1980). Transport of proteins into mitochondrla: postranslational transfer of ADPIATP carrier into mitochondria in vitro. Eur. J. Biochem. 109, 217-229.

Zwizinski, C., and Neupert, W. (1983). Precursor proteins are transported into mitochondria in the absence of proteolytic cleavage of the additional sequences. J. Biol. Chem. 258, 13340-13346.

Zwizinski, C., Schleyer, M., and Neupert, W. (1984). Proteinaceous receptors for the import of mitochondrial precursor proteins. J. Biol. Chem. 259, 7850-7856. 